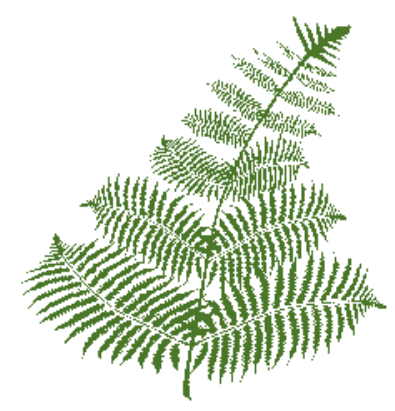

ILMARI IVAska ja Kirsti Sittonen

\title{
tehdessä-konstruktio edistyneessä oppijansuomessa
}

\section{Korpusanalyysin ja oikeakielisyysarviointien ristivalotus}

\section{Johdanto}

Monia suomen infinitiivikonstruktioita pidetään kielenoppimisen kannalta kompleksisina rakenteina. Tällaisten moniosaisten ja siksi morfologisesti mutkikkaiden rakenteiden muodostus vaatii samanaikaisesti sekä verbien että nominien taivutustyyppien tuntemista ja tunnistamista. Tämän lisäksi useat infinitiivikonstruktiot ovat abstrakteja ja kognitiivisesti kompleksisia sekä syntaktiselta funktioltaan että semanttiselta tulkinnaltaan: monet niistä nominalisoivat verbikonstruktioita ja kokonaisia sivulauseita sekä ilmaisevat aika- tai kausaalisuhteita. Tämä infinitiivikonstruktioiden oletettu monimutkaisuus heijastuu myös suomi toisena tai vieraana kielenä -opetuksen $\left(\mathrm{S}_{2}\right)$ oppikirjoihin niin, että infinitiivikonstruktioita käsitellään oppikirjoissa vasta melko myöhäisessä vaiheessa, kun verbi- ja nominitaivutuksen päämekanismit ja keskeiset taivutustyypit on käsitelty. Infinitiivikonstruktioiden opetustraditio sisältääkin ajatuksen kielitaidon kumulatiivisesta kehittymisestä siten, että infinitiivikonstruktioiden hallinta edistyy vähittäin, kun konstruktioiden osatekijät ovat oppijan hallinnassa.

Seuraamme tässä tutkimuksessa ennen kaikkea Siitosen (2014) avaamaa tutkimuslinjaa eli tarkastelemme inessiivisijaisen E-infinitiivikonstruktion esiintymiä S2-kirjoittajien ja ensikielenään suomea $\left(\mathrm{S}_{1}\right)$ kirjoittavien akateemisissa teksteissä ja vertaamme näitä toisiinsa. Tarkastelemme konstruktion aktiivi- ja passiivivarianttia, jotta voimme havaita käytössä mahdollisesti esiin nousevat konstruktion eri merkitysten käyttöerot eli sen käyttöalan supistumat, laajentumat ja näiden väliset yhteydet. Pyrimme tarkentamaan fokusta siihen, missä määrin S2- ja S1-kirjoittajien välillä havaittavat käyttöerot ovat tekstilajikohtaisia ja missä määrin erot ovat yhteydessä konstruktion eri merkityksiin. Aineistomme on osa Edistyneiden suomenoppijoiden korpusta (LAS2; Ivaska 2014c). Toisaalta selvitämme, miten S1-puhujat kokevat konstruktion laadullisen kohdekielenmukaisuuden. Tätä varten olemme toteuttaneet kaksi kyselytutkimusta. LAS2:sta poimitut esimerkit havainnollistavat aktiivista (1) ja passiivista (2) konstruktiota; tarkastelunalaiset konstruktiot on lihavoitu (ks. myös VISK $\$ 120$ ). 
(1) Jos oppijan L2-kielen taito ei opetuksen alkaessa ole kovin hyvä (las2vtto1verto29) ${ }^{1}$

(2) Lausesemantiikkaa tarkasteltaessa sanat jaetaan sisältö- ja muotosanoihin. (las2-vtto1verto25)

Vertaamme toisiinsa myös toisiaan lähellä olevia akateemisen kirjoittamisen tekstilajeja ja S2- ja S1- kirjoittajien tekstejä. Pyrimme näin ottamaan huomioon havainnon, että akateemiseen kielenkäyttöön kuuluvien, keskenään samankaltaistenkin tekstilajien ominaispiirteissä saattaa olla suuria eroja (ks. esim. Biber 2006). Tutkimus nivoutuukin osaksi konteksti- ja tekstilajikohtaista näkemystä kielenkäytöstä ja -oppimisesta. Tämä puolestaan vastaa monilta osin käyttöpohjaista ajatusta kielijärjestelmästä.

Oppijankielen kompleksisuutta voidaan tarkastella myös sen kohdekielenmukaisuuden kautta. Näkemyksemme mukaan kohdekielenmukaisuus on jatkumomaista ja kielensisäinen vaihtelu osa itse kielijärjestelmää. Ottaaksemme tämän kielensisäisen vaihtelun huomioon perustamme tulkintamme oman intuitiomme sijaan oikeakielisyysarviointeihin pohjaavaan kielenkäyttäjien jaettuun näkemykseen. Kielenkäyttäjäkunnan todentamat poikkeamat kohdekielestä osoittavat laadullista horjuntaa vielä edistyneenkin kielitaidon tasoilla. Laajemman arvioijajoukon tulkinnat antavat monipuolisemman ja selvemmin todelliseen kielenkäyttöön perustuvan kuvan kuin tutkijoiden intuitionsa avulla tekemät tulkinnat.

Tutkimuskysymyksemme ovat seuraavat:

1) Minkälaista on inessiivisijaisten E-infinitiivikonstruktioiden käyttö edistyneiden suomenoppijoiden ja ensikielisten suomenpuhujien teksteissä? Käyttöä tutkitaan sekä määrällisesti että laadullisesti akateemisen kirjoittamisen eri tekstilajeissa.

2) Havaitsevatko ensikieliset suomenpuhujat edistyneiden suomenoppijoiden tuottamien E-infinitiivikonstruktioiden poikkeamia kohdekielestä ja ovatko heidän havaintonsa ja tulkintansa keskenään samankaltaisia?

Artikkeli rakentuu seuraavasti: luvussa 2 käsittelemme tutkimuksen teoreettista viitekehystä ja esittelemme lyhyesti aiempia tuloksia. Luvussa 3 kuvaamme tutkimuksen aineiston ja menetelmät. Luvussa 4 puramme korpuspohjaisen analyysin ja oikeakielisyysarviointien tulokset. Oikeakielisyysarviointien yhteydessä analysoimme myös laadullisesti tapauksia, jotka nousevat arvioinneissa esiin kohdekielenvastaisina konstruktioina. Lopuksi luvussa 5 arvioimme tulosten merkitystä, käyttämäämme menetelmää ja sen soveltuvuutta oppijankielen tutkimukseen. Pyrimme lisäksi liittämään tulokset osaksi keskustelua, joka koskee kielen kompleksisuutta ja erityisesti sen suhdetta kielenoppimiseen ja edistyneeseen kielitaitoon.

1 Merkintä kertoo esimerkin sijainnin korpuksessa, ja vert koodin osana kertoo, että kyse on S1-aineistosta. 


\section{Teoreettinen viitekehys ja aiempi tutkimus}

Lähestymme tutkimuskohdettamme kognitiivisen konstruktiokieliopin näkökulmasta. Näemme kielijärjestelmän muodostuvan abstraktiudeltaan vaihtelevista konstruktioista, jotka puolestaan koostuvat muodon ja merkityksen tai funktion toistuvasta ja vakiintuneesta yhteydestä (kognitiivisesta konstruktiokieliopista tarkemmin, ks. Goldberg 1995; 2006). Tämä järjestelmä on jatkuvassa muutoksessa ja perustuu todelliseen kielenkäyttöön ja siihen pohjautuviin todennäköisiin kielellisiin toimintatapoihin (käyttöpohjaisesta ajattelusta tarkemmin, ks. Hopper 1987; Bybee-Thompson 2007; Larsen-Freeman-Cameron 2008; Cadierno-Eskildsen 2015).

Oppijankielen tutkimuksessa kompleksisuuden käsitettä on pohdittu paljon. Bultén ja Housenin $(2012,27)$ mukaan kompleksisuus pitäisi kuitenkin määritellä nykyistä tarkemmin. Yhtenäistä linjaa ei ole helppo löytää; jo kielikohtaiset erot ovat suuret. Morfologisesti rikkaassa kielessä kompleksisuus on eriluonteista kuin esimerkiksi kielessä, jossa sanajärjestys ilmentää semanttisia eroja. Tässä tutkimuksessa kyse on Bultéa ja Housenia seuraten rakenteelliseen kompleksisuuteen kuuluvasta formaalisesta ja funktionaalisesta kompleksisuudesta. Formaaliseen kompleksisuuteen kuuluu morfologinen ja funktionaaliseen syntaktinen kompleksisuus. Nämä molemmat kuuluvat lingvistiseen kompleksisuuteen ja siinä erityisesti kieliopilliseen kompleksisuuteen (ks. Bulté-Housen 2012, 23, 25, 27, erityisesti kuvio 1).

Morfologian näkökulmasta kompleksinen konstruktio koostuu esimerkiksi monista taivutuselementeistä - rakenteen moninaisuudessa voi olla variaatiota pääluokan, infiniittisten tunnusten, sijamuotojen ja liitteiden valinnassa. Syntaksissa otetaan huomioon lauseenjäsenten ja lauseiden keskinäiset suhteet. Infiniittisillä rakenteilla on rakenteen sisäiset syntaktiset suhteet osien kesken sekä rakenteen ulkopuoliset viittaussuhteet pääasiallisesti virkkeeseen, johon rakenne on upotettu. Suhteet voivat rakentua päällekkäisesti niin, että yksi ilmaus on huomioitava usein eri tavoin. Tällöin ilmaus ilmentää useampaa kompleksisuutta. (Bulté-Housen 2012, 27, 31, 35, erityisesti kuvio 2.) Infiniittiset rakenteet sovittautuvat syntaktisesti hallitsevaan lauseeseen, jossa konstruktio täyttää myös semanttisen tehtävän. Tämä tehtävä saattaa poiketa morfologisesta perusfunktiosta. Näin sekä rakenteellinen että semanttinen variaatio lisäävät osaltaan kompleksisuutta.

Aiemmassa tutkimuksessa rakenteellista kompleksisuutta on lähestytty monin eri mittarein, usein määrällisen runsauden näkökulmasta - esimerkiksi tutkimalla lauseiden sanamäärï (mittausmenetelmistä ks. esim. Wolfe-Quintero ym. 1998). Kuten Martin kuitenkin huomauttaa, lauseiden ja virkkeiden pituuden ja suhteiden laskeminen ei ole mielekästä suomen kaltaisissa kielissä, joissa on kompakteja mutta hyvin ilmaisuvoimaisia infinitiivikonstruktioita (Martin 2013). Tämä huomio pätee erinomaisesti myös tässä tutkittavaan E-infinitiivikonstruktioon.

Inessiivisijainen E-infinitiivikonstruktio on monimutkainen niin morfologialtaan kuin syntaktis-semanttiselta funktioltaankin. Muoto koostuu sanavartalosta, infinitiivin -e-tunnuksesta sekä inessiivin sijapäätteestä -ssA. Passiivimuotoisissa konstruktioissa 
infinitiivin tunnusta edeltää passiivin tunnus ja aktiivimuotoisissa sijapäätettä voi seurata omistusliite. (VISK $\$ 120$.$) Esimerkki 3$ kuvaa aktiivista omistusliitteetöntä, esimerkki 4 passiivista ja esimerkki 5 aktiivista omistusliitteellistä konstruktiota. Konstruktiolla saattaa myös olla - useimmiten genetiivisijainen - subjekti, kuten esimerkin 3 keskustelun.

(3) Keskustelun edetessä puheenvuorot voivat pidentyä ja lomittua. (las2vtto1verto89)

(4) - - vaikka se on yksi keskeinen ero vesistöitä verrattaessa toisiinsa. (las2vtto1verto82)

(5) Jaollinen objekti ei lisääntyessään muuta olomuotoaan, esim maitoa maitoa maitoa. (las2-vtto1verto88)

Konstruktion syntaktinen funktio on tyypillisesti adverbiaalimäärite, joka ilmaisee konstruktion ilmaiseman teon ajankohtaa (VISK \$ 495), joka on ainakin osin päällekkäinen finiittisen rakenteen kanssa (VISK $\$ 543, \$ 544, \$ 1122$ ). Konstruktion parafraasit ovat usein kun-alkuisia sivulauseita, kuten 'kun keskustelu etenee, puheenvuorot voivat [...]' (3), '[...] on yksi keskeinen ero, kun vesistöjä verrataan toisiinsa' (4) tai '[...] ei muuta olomuotoaan, kun se lisääntyy' (5). Herlinin (1998, 183) mukaan kaikilla kunsanan käyttötavoilla näyttää olevan motivoitunut yhteys temporaalisuuteen, joka on myös E-infinitiivikonstruktion prototyyppinen merkitystulkinta. (Kun-lauseen merkitystulkinnoista ks. esim. Herlin 1998; VISK $\$ 1121-\$ 1123, \$ 1128, \$ 1134, \$ 1137$.$) E-infinitiivi-$ konstruktio hahmottuu konstruktion ja sen kehyslauseen välisen semanttisen suhteen merkitsimeksi (vrt. VISK \$1121). ISK:n (VISK \$545) mukaan konstruktion semanttinen tulkinta on joskus lähempänä kontrastiivista suhdetta (VISK $\$ 1102$ ), kausaalisuhdetta (VISK $\$ 1128$ ) tai kuvatun tilanteen ehdollisuutta (VISK $\$ 1134$ ) tai kahden tilanteen rinnasteisuutta (VISK $\$ 545$ ). ISK (mp.) mainitsee konstruktion yhdeksi käyttötavaksi rinnastuksen kaltaisen kahden tasaveroisen tilanteen välisen suhteen kuvaamisen. Tämä on kuitenkin ilmiönä tekstuaalis-funktionaalinen, mistä syystä sitä ei ole syytä käsitellä rinnakkain konstruktion merkitystä kuvaavien käyttötapojen kanssa.

Nykykielessä konstruktio on Herlinin ja Kotilaisen (2005, 284-286) mukaan jakautunut syntaktisesti kahtia lausemaisiin käyttöympäristöihin tai tarvittaessa-ilmauksen kaltaisiin merkitykseltään ja muodoltaan kiteytyneisiin leksikaalistuneisiin käyttötilanteisiin. Herlinin ja Kotilaisen (mp.) mukaan on osin harhaanjohtavaa puhua eri merkityksistä tai merkityksen eriytymisestä, sillä kyse on heidän mukaansa ennemmin merkityksen haalistumisesta yleiseksi kahden prosessin välisen suhteen ilmaisimeksi.

Konstruktion käyttö eri merkityksissä on muuttunut osana kirjoitetun suomen konventioiden muotoutumista, ja konstruktion eri merkitysten tyypillisyys riippuu edelleen tekstilajista. Ensinnäkin konstruktio on yleistynyt kirjakielen kehityksen aikana huomattavasti: Herlinin ja Kotilaisen $(2005,261)$ mukaan sen määrä viisinkertaistui vuoden 1642 raamatunkäännöksestä Lönnrotin 180o-luvun teksteihin mennessä. Lisäksi konstruktio esiintyy tutkijoiden käyttämässä murreaineistossa puhtaasti ajan adverbiaalina, niin että sillä viitataan tilanteisiin, jotka tunnetaan puhetilanteessa joko yleisen maailmantiedon, tapahtuman toistuvuuden tai prosessin aiemman maininnan vuoksi (mt., 265-266). 
Ikolan, Palomäen ja Koiton $(1989,386)$ mukaan konstruktio esiintyy kirjoitetussa kielessä noin kymmenen kertaa niin usein kuin puhekielessä (19 esiintymää / 1 ooo sanetta vs. 2 esiintymää / 1000 sanetta; temporaalirakenteen käytöstä ks. myös Lindén 1961; 1971). Vastaava trendi välittyy myös tarkasteltaessa Kielipankin Korp-käyttöliittymän ${ }^{2}$ avulla kaikkien E-infinitiivin inessiivien esiintymiä Kansalliskirjaston lehtikokoelman 1990- ja 2000-luvun aineistoissa ja Lauseopin arkiston murrekorpuksessa: sanomalehtiaineistossa muotoa esiintyy 0,85 / 1000 sanetta, kun taas murreaineistossa muotoa esiintyy 0,3 / 1000 sanetta. Niin Eskola (2002, 137) kuin Herlin ja Kotilainenkin $(2005,288)$ toteavat konstruktion ei-temporaalisen käytön kuuluvan ennen kaikkea asiatekstien kirjoituskäytänteisiin, mikä taas saattaa liittyä muiden kielten nimenomaan kirjoitettuun suomeen kohdistuneeseen vaikutukseen (Herlin-Kotilainen 2004).

Todellisesta variaatiosta poiketen E-infinitiivikonstruktion käyttöä koskevat hyvän yleiskielen ohjeistukset ovat konservatiivisia ja ne korostavat konstruktion temporaalista merkitystä. Esimerkiksi Osmo Ikola toteaa vuonna 2000 ilmestyneessä Pienessä nykysuomen oppaassa seuraavasti: "Ellei temporaalista lauseenvastiketta voi muuttaa temporaaliseksi sivulauseeksi, on lauseenvastiketta käytetty väärin" (Ikola 2000, 170). Samoin Uusi kieliopas suosittelee, että "[y]leensä ei temporaalista lauseenvastiketta [- - ] pitäisi käyttää jos-lauseen sijasta" (Itkonen-Maamies 2007, 83). Vastaavasti Kirjoittajan ABC-kortti -verkkosivulla ${ }^{3}$ todetaan seuraavasti: "Temporaalinen lauseenvastike korvaa kun-lausetta ja ilmaisee siten aikaa. Niinpä sitä ei pidä käyttää esimerkiksi korvaamassa jos-, vaikka- tai koska-lausetta." Kielenkäyttöä ohjeistavat lähdeteokset ovat siis verrattain kaukana konstruktion todellisessa käytössä esiintyvästä variaatiosta.

Käyttöpohjaisen oppimiskäsityksen mukaan oppija havainnoi vastaantulevien kielenilmausten keskinäisiä samankaltaisuuksia ja erilaisuuksia niin muodon, merkityksen kuin käytönkin osalta. Hän hahmottaa havaintojensa avulla analogisesti kulloisenkin muodon ja merkityksen sekä käyttöyhteyden kokonaisuuden ja kytkee sen näin asteittain osaksi omaa kielijärjestelmäänsä (ks. esim. Tomasello 2003). Käyttöpohjaisen ajattelun mukaan omaksumista täytyy edeltää riittävä syötös ja tunnistaminen eli opittavan muodon käytön havaitseminen. Konstruktioiden merkityksen oppimisen on osoitettu alkavan tyypillisesti rakenteiden prototyyppisistä merkityksistä ja näille merkityksille tyypillisistä lekseemeistä ja laajentuvan eri käyttöyhteyksiin (ks. esim. Goldberg ym. 2004; GoldbergCasenheiser 2008; Martin ym. 2010). Osa syötöksestä saattaa tulla luokkahuoneympäristössä tai oppikirjojen kautta, mutta koska E-infinitiivikonstruktio on tyypillinen erityisesti kirjoitetussa kielessä, sen tyypillisen käytön oppiminen edellyttää kykyä lukea ja ymmärtää suomenkielisiä tekstejä.

Konstruktioiden määrällisesti ja laadullisesti kohdekielinen käyttö edellyttää siis taitoa muodostaa rakenteet ja kykyä ymmärtää niiden syntaktis-semanttiset funktiot sekä

2 https://korp.csc.fi

3 http://webcgi.oulu.fi/oykk/abc/kielenhuolto/lauseopillisia_ilmioita/lauseenvastikkeet/temporaalinen_lauseenvastike/ 
tyypillinen konteksti- ja tekstilajikohtainen käyttö. Perinteisesti kielenilmausten kohdekielenmukaisuutta on lähestytty lähinnä tutkijan oman intuition avulla. Kohdekielimäisyys ei kuitenkaan ole yksiselitteistä, ja esimerkiksi Bybee ja Eddington (2006) osoittavat, että ensikieliset kielenkäyttäjät arvioivat usein esiintyvät ja niiden kanssa merkitykseltään samankaltaiset muodot oikeakielisemmiksi kuin harvemmin esiintyvät mutta laadullisesti samanlaiset muodot. Myös Dąbrowska (2008) osoittaa konstruktioiden prototyyppisten muotojen saavan yleensä selvästi korkeamman oikeakielisyysarvion kuin saman konstruktion vähemmän prototyyppisten muotojen. Tutkittaessa E-infinitiivin kaltaista kompleksista konstruktiota S2-näkökulmasta onkin mielenkiintoista nähdä, miten ensikieliset suomenpuhujat arvioivat edistyneiden suomenoppijoiden tuotoksia. Keskenään yhdenmukaiset arviot tukevat nähdäksemme ajatusta konstruktion laadullisesta tyypillisyydestä ja arvioiden vaihtelu taas indikoi yksilöllistä vaihtelua. Alhaiset oikeakielisyysarviot ovat siis ensisijaisesti epäprototyyppisyyden ja kohdekielenvastaisuuden indikaattoreita. Täten ne todennäköisesti osoittavat omaksumisen osittaisuutta ja sitä, että oppijan kielijärjestelmä poikkeaa joiltakin osin ensikielisten järjestelmästä.

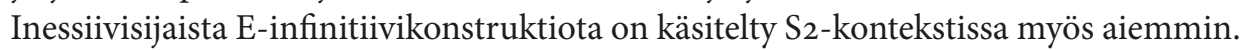
Tämän artikkelin kannalta keskeisin on Siitosen (2014) tutkimus, sillä sen kohteena ovat konstruktion passiivimuodot edistyneessä oppijansuomessa ja aineisto on osin samaa

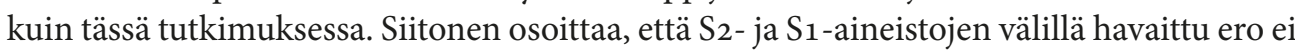
selity yksittäisten tai tiettyjen harvojen lekseemien käyttöerolla vaan erolla nimenomaan konstruktioiden käytössä. S2-kirjoittajista vain alle kolmannes käyttää konstruktiota, S1-tekstien kirjoittajista kuitenkin lähes puolet. Lisäksi konstruktiota käyttävistä S2-kirjoittajista yli puolella ainakin osa konstruktioista on laadullisesti kohdekielenvastaisia.

S2-näkökulmasta konstruktiota ovat käsitelleet myös Eklund (1996) ja Tolvanen (2004). Eklundin (1996) S2-aineisto koostuu Helsingin yliopiston Suomen kielen ja kulttuurin sekä muiden edistyneille tarkoitettujen suomen kielen kurssien ja S1-aineisto tieteellisen kirjoittamisen kurssien teksteistä. Aineistojen välillä ei ole huomattavia määrällisiä käyttöeroja (mt., liite 2), mutta erityisesti konstruktion viittaussuhteet näyttävät aiheuttavan laadullisia ongelmia konstruktion tulkinnassa (mt. 83). Tolvasen (2004) aineisto puolestaan koostuu ylioppilasaineista, joissa hän toteaa infiniittisten konstruktioiden olevan melko harvinaisia niin S2- kuin S1-kirjoitelmissakin - kummassakin osaaineistossa noin kolmanneksessa aineista on joko yksi tai ei ainuttakaan Tolvasen lauseenvastikkeeksi luokittelemaa infiniittistä konstruktiota (mt. 33).

Käyttöpohjaiseen kielikäsitykseen kuuluu ajatus kielen funktionaalisesta luonteesta; monet kielelliset valinnat riippuvat niiden käyttöympäristöstä (ks. esim. Sinclair 1991, 112). Tekstilaji onkin keskeinen tekijä kielen oppimisessa. Swalesin $(1990,58)$ mukaan tekstilajit ovat kommunikaatiotilanteita, joiden osanottajat jakavat samat kommunikatiiviset tavoitteet ja jotka ovat samankaltaisia rakenteellisesti, tyylillisesti ja sisällöllisesti sekä myös vastaanottajien osalta. Berkenkotterin ja Huckinin (1995, ix) mukaan tekstilajitietoisuus koostuu kielenkäyttäjän kyvystä toimia kielellisesti tyypillisellä tavalla samankaltaisina toistuvissa tilanteissa. Nämä kielelliset toimintamallit puolestaan kehkeytyvät 
Hylandin (2004, 55-56) mukaan nimenomaan käyttöpohjaisesti syötöksen ja siitä tehtävien havaintojen ja yleistysten avulla. Tyypillinen kielellinen toiminta vaatii siis sekä rakenteiden laadullista hallintaa että kykyä toimia tilannekohtaisesti odotetulla tavalla, ja oppimisen kannalta laadulliset taidot edeltävätkin kontekstisidonnaista tyypillisyyttä (ks. esim. Olshtain-Blum-Kulka 1985; Bardovi-Harlig-Dörnyei 1998).

Olemme tässä tutkimuksessa päätyneet seuraamaan Biberin ja Conradin $(2009,2)$ määritelmiä, joiden mukaan tekstilaji koostuu tietynlaisista teksteistä, kun taas rekisteri kuvaa niitä kielellisiä piirteitä, joita tyypillisesti käytetään tietynlaisissa tilanteissa tietynlaisten kommunikatiivisten tavoitteiden saavuttamiseksi. Akateemiset tekstit mainitaan usein esimerkkinä tietystä rekisteristä, vaikka tosiasiassa akateemisen kielenkäytön sisäinen vaihtelu on runsasta niin siinä esiin nousevien rekisterien kuin tekstilajienkin osalta. Esimerkiksi Biber ja Conrad kuvaavat akateemista kirjoittamista seuraavasti:

[Academic writing is] written language that has been carefully produced and edited, addressed to a large number of readers who are separated in time and space from the author, and with the primary communicative purpose of presenting information about some topic (Biber-Conrad 2009, 32).

Kuvaavaa on, että jo tämä luonteeltaan yleinen määritelmä rajaa ulkopuolelle monia akateemiselle kirjoittamiselle tyypillisiä tekstilajeja, kuten kurssityönä tuotettavat esseet ja tenttivastaukset. Mahdollista vaihtelua synnyttäviä tekijöitä on runsaasti: tekstien ensisijainen funktio, kommunikaation ensisijaiset osallistujat ja heidän asemansa akateemisessa yhteisössä, tekstien julkisuus, tekstien tuottamistilanne ja osallistujien mahdollisuudet valmistautua tekstin tuottamiseen, mahdollisuus käyttää apuvälineitä sekä se akateeminen ala, johon tekstit kuuluvat (ks. esim. Biber ym. 2002; 2004; Biber 2006). Biber (2006) osoittaa, että niin leksikaalisten kuin kieliopillistenkin piirteiden vaihtelu on runsasta sekä erilaisten tekstilajien että myös eri alojen välillä. Akateemisessa kontekstissa käytettyä, ensikielenään jotakin muuta kuin englantia puhuvien kirjoittajien englantia onkin alettu etenkin viimeisen kymmenen vuoden aikana tutkia nimenomaan korpustutkimuksen menetelmin sisäisen variaation (ks. esim. Callies 2013; Callies-Zaytseva 2013; Chen 2013; Schutz 2013) ja usein myös opetukseen soveltamisen näkökulmasta (ks. esim. Conrad 2005; 2011; O’Keeffe ym. 2007; Aijmer 2009; Meunier 2012). Paquot ja muut (2013) osoittavat, että vielä edistyneetkin kielenoppijat ilmaisevat oman näkökulmansa esimerkiksi akateemisissa teksteissä ensikielisiä kielenkäyttäjiä eksplisiittisemmin ja useammin tieteenalasta riippumatta.

\section{Materiaali ja menetelmät}

Tutkimus jakautuu niin materiaalien kuin menetelmienkin osalta kahteen osaan - korpuspohjaiseen määrällis-laadulliseen analyysiin ja sen pohjalta koostettuun kyselytutkimukseen todellisten tekstilauseiden oikeakielisyysarvioinneista. Esittelemme tästä syystä aineiston ja menetelmät kahdessa osassa. 


\subsection{Korpuspohjainen analyysi}

Tarkastelemme LAS2:n (Ivaska 2014c) avulla kolmea akateemisen kirjoittamisen tekstilajia: tenttivastauksia (tentit), pro gradu -käsikirjoituksia (gradut) ja esseitä (esseet). Tekstilajit ovat monilta osin samankaltaisia, mutta ne poikkeavat toisistaan niin tuottamistilanteen, ensisijaisen funktion kuin oletetun lukijakunnankin osalta. Tentit on kirjoitettu valvotussa tilanteessa käsin, kun taas gradut ja esseet on kirjoitettu valvomattomissa olosuhteissa niin, että kirjoittajan on myös ollut mahdollista konsultoida lähteitä ja saada apua. Tenttien ensisijaisena funktiona on osoittaa kirjoittajan tiedot ja taidot opiskellusta sisällöstä, gradujen tavoitteena on osoittaa kirjoittajan kyky akateemisen tutkimuksen tekoon, kun taas esseissä kirjoittaja pyrkii kuvaamaan omia ajatusprosessejaan ja tulkintamalleja sekä muodostamaan perusteltuja mielipiteitä opiskellusta sisällöstä. Siinä missä tentit ja esseet ovat luonteeltaan yksityisiä ja tarkoitettu ensisijaisesti opettajan luettaviksi, gradukäsikirjoitusten lopputuotteena julkaistavat gradut ovat saatavilla myös muiden luettaviksi. Tekstilajien rinnakkainen tarkasteleminen $S_{2}$ - ja $S_{1}$-aineistossa helpottaa havainnoitavan ilmiön ymmärtämistä. Samalla se auttaa tulkitsemaan konstruktioiden käyttöön vaikuttavia tekijöitä ja infinitiivikonstruktioiden ja tekstilajin suhdetta kielen kompleksisuuteen. Taulukko 1 kuvaa käyttämämme korpusaineiston koon.

$\mathrm{LAS}_{2}$ on annotoitu, xml-muotoon tallennettu tekstikorpus, jonka tekstit on rakenteistettu kappaleisiin, virkkeisiin ja lauseisiin. LAS2 on digitoitu alkuperäisistä teksteistä manuaalisesti tai muuntamalla tietokoneohjelman avulla, koodattu kielellisin metatiedoin lemmojen, sanaluokkien, morfologisten muotojen ja syntaktisten funktioiden osalta. Koodaus on kohdistettu sanatasolle, joten yhdellä sanalla saattaa olla samanaikaisesti useita morfologisia koodeja. (Ks. tarkemmin Ivaska 2014c.)

Taulukko 1. Korpusaineiston koko ja jakauma osa-aineistoittain.

\begin{tabular}{|l|r|r|r|r|}
\hline \multirow{2}{*}{} & \multicolumn{2}{|c|}{ S2-aineisto } & \multicolumn{2}{c|}{ S1-aineisto } \\
\cline { 2 - 5 } & $\begin{array}{c}\text { Tekstien } \\
\text { määrä }\end{array}$ & $\begin{array}{c}\text { Saneiden } \\
\text { määrä }\end{array}$ & $\begin{array}{c}\text { Tekstien } \\
\text { määrä }\end{array}$ & $\begin{array}{c}\text { Saneiden } \\
\text { määrä }\end{array}$ \\
\hline Tenttivastaukset (TENTTI) & 120 & 70552 & 120 & 58630 \\
\hline Pro gradu -käsikirjoitukset (GRADU) & 16 & 29435 & 16 & 39492 \\
\hline Esseet (ESSEE) & 32 & 16375 & 32 & 22807 \\
\hline Yhteensä & $\mathbf{1 6 8}$ & $\mathbf{1 1 6 3 6 2}$ & $\mathbf{1 6 8}$ & $\mathbf{1 2 0} \mathbf{9 2 9}$ \\
\hline
\end{tabular}

Korpusanalyysimme on otteeltaan korpuspohjainen. Olemme siis valinneet aiemman tutkimuksen ja omien havaintojemme perusteella tietyn kielen konstruktion - inessiivimuotoisen E-infinitiivikonstruktion - jonka tyypillistä käyttöä ja käytössä esiintyvää vaihtelua tarkastelemme korpusaineiston avulla. Menetelmä on sekä kuvaileva että vertaileva, sillä tarkastelemme käyttöä ylipäätään ja myös eri osa-aineistoissa. Lisäksi vertailemme osa-aineistoja keskenään. Tältä osin tutkimuksemme seuraa oppijankielen korpustutkimuksessa yleistä kontrastiivista välikielianalyysia (engl. Contrastive Interlanguage Analysis - CIA; Granger 1996; 2015). Vertailu on monitasoista: vertaamme toisiinsa sekä

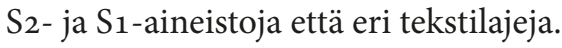


Lähtökohtanamme ovat morfologisesti määriteltyjen E-infinitiivikonstruktioiden käyttöfrekvenssit. Käyttöfrekvenssien ja niihin perustuvien tulkintojen lisäksi perehdymme konstruktion laadullis-funktionaaliseen vaihteluun. Pyrimme näin vastaamaan CIA-tutkimusta kohtaan esitettyyn kritiikkiin siitä, että menetelmää soveltavat tutkimukset keskittyvät yksittäisten kielenpiirteiden frekvenssieroihin ja jättävät huomiotta niiden käyttöympäristön ja sen sisällään pitämät kielelliset ja kielenulkoiset muuttujat (ks. esim. Gries-Deshors 2014). Tutkimme ennen kaikkea sitä, miten konstruktiota käytetään eri tekstilajeissa, mitkä ovat sille tyypillisiä leksikaalisia representaatioita ja mitä funktioita se tyypillisesti ilmaisee. Käytännössä korpusanalyysi käsittää seuraavat vaiheet:

1. Kootaan kooltaan tasapainoinen otos tarkasteltavien tekstilajien tekstejä siten, että niitä on S2- ja S1-aineistossa kustakin tekstilajista yhtä paljon;

2. Haetaan kaikki inessiivisijaisen E-infinitiivikonstruktion esiintymät;

3. Tehdään tilastollinen vertailu konstruktion käyttöfrekvensseistä S2- ja S1-aineistojen sekä eri osa-aineistojen välillä;

4. Käydään läpi kaikki konstruktioesiintymät kontekstissaan sekä tulkitaan ja koodataan aineistoon niiden ensisijainen merkitys. Muuttujan mahdolliset arvot ovat aikasuhde, syysuhde ja ehtosuhde (VISK $\$ 543-\$ 545$ );

5. Tarkastellaan konstruktion eri merkitysten käyttöaloja, skemaattisuutta ja leksikaalista jakaumaa eri osa-aineistoissa.

Konstruktioiden merkitysten luokittelu on väistämättä tulkinnanvaraista, ja nyt käsillä olevan kaltaisen monimerkityksisen tai merkitykseltään haalistuneen konstruktion tapauksessa tämä on vielä ilmeisempää. Kausaalisuus ja konditionaalisuus ovat jo itsessään jatkumomaisia ilmiöitä. Noordman ja de Blijzer (2000) osoittavat kausaalisten ilmausten merkityksen ymmärtämisen riippuvan samanaikaisesti sisällön ja episteemisten kytkösten välisestä suhteesta sekä syyn ja vaikutuksen (engl. cause and effect) välisestä lineaarisesta ja myös käsitteellisestä järjestyksestä. Nyt käsillä oleva konstruktio kuvaa prototyyppisesti aikasuhdetta - myös kaikissa aineistomme konstruktioissa temporaalinen tulkinta on mahdollinen, ja esimerkiksi kiteytyneissä mennessä ja kuluessa -tapauksissa se lienee ainoa tulkinta. Muissa tapauksissa olemme valinneet ensisijaiseksi tulkinnaksi kontekstin parhaiten tukeman vaihtoehdon. Käytimme tulkinnan apuna kutakin merkitystä vastaavaa parafraasia seuraavasti: konditionaalisena parafraasina oli 'sillä ehdolla, että, kausaalisena parafraasina 'siitä syystä, että' ja ne tapaukset, joihin kumpikaan parafraasi ei sopinut, tulkitsimme ensisijaisesti temporaalisiksi. Epäselvimmät tapaukset olisi nähdäksemme voinut jättää käsittelemättä tai soveltaa luokittelussa epäselvät-kategoriaa tai pyrkiä löytämään todennäköisimmät ratkaisut. Olemme päätyneet viimeiseen vaihtoehtoon keskustelemalla monitulkintaisimmista tapauksista yhdessä ja valinneet tulkinnan, joka tyydyttää kumpaakin kirjoittajaa.

Kaikki hakutulokset on tallennettu LAS2-hakutyökalujen avulla csv-muotoon. Tilastolliset analyysit on tehty R-ohjelmointiympäristössä (R Core Team 2015). Käyttöfrekvenssien tilastollisessa tarkastelussa olemme käyttäneet tekstikohtaisia suhteellisia 
frekvenssejä eli esiintymien määrää kussakin tekstissä tuhatta sanetta kohti. Frekvensseissä havaittujen tilastollisten erojen testinä olemme käyttäneet Mann-Whitneyn U-testiä, joka on luonteeltaan epäparametrinen eikä näin ole herkkä esiintymien epäsymmetrisille jakaumille. Konstruktion skemaattisuutta tarkastelemme vertaamalla konstruktion esiintymäfrekvenssiä eli konstruktioiden absoluuttista märää ja tyyppifrekvenssiä - tässä tapauksessa sitä, kuinka monta eri verbilekseemiä konstruktiossa esiintyy (ks. BybeeThompson 1997). Leksikaalista jakaumaa ja eri osa-aineistoja toisistaan erottavia lekseemejä tarkastelemme distinktiivisen kollekseemianalyysin avulla. Karkeistaen analyysissa verrataan jonkin konstruktion ja jonkin sen piirteen - kuten tietyn lekseemin - välisen yhteyden vahvuutta vertaamalla näitä kummankin kokonaismääriin aineistossa. Menetelmä on kehitetty alun perin funktioltaan samankaltaisten konstruktioiden leksikaalissemanttisten preferenssien tarkasteluun (Gries-Stefanowitch 2004). Sitä on käytetty tämän tutkimuksen tapaan myös saman konstruktion leksikaalis-semanttisten käyttöerojen tarkasteluun eri osa-aineistoissa (ks. esim. Gries-Hilpert 2008; Ivaska 2015).

\subsection{Kyselytutkimukset}

Kyselytutkimuksemme seuraavat aiempien käyttöpohjaisten oikeakielisyysarviointien tutkimusasetelmaa (ks. esim. Dąbrowska 2004; 2008; Bybee-Eddington 2006). Toteutimme kaksi osin päällekkäistä kyselytutkimusta: kyselytutkimus 1 muodostaa pääasiallisen kyselytutkimusaineistomme, kun taas kyselytutkimus 2 tarkentaa joitakin tutkimuksen kannalta relevantteja kysymyksiä. Informantit vastasivat kyselyihin kynällä ja paperilla, ja kerätyt vastaukset on digitoitu csv-muotoon. Oman tulkintamme mukaan osa kyselyn virkkeistä on täysin kohdekielenmukaisia, kun taas osassa virkkeistä on jotakin yllättävää nimenomaan tutkitussa infinitiivikonstruktiossa.

\section{Kyselytutkimus 1}

Kyselytutkimuksessa 1 vastaajia pyydettiin arvioimaan 44 suomenkielisen LAS2-korpuksen virkkeen oikeakielisyyttä viisiportaisella asteikolla niin, että vastaajan mielestä (1) on yksiselitteisesti epäkieliopillinen ja (5) yksiselitteisesti kieliopillinen. Virkkeistä kymmenessä esiintyi tutkimuskohteemme E-infinitiivikonstruktio ja lopuissa jokin muu infinitiivikonstruktio. Näin pyrimme välttämään ns. priming-ilmiötä eli vastaajien virittymistä tulkitsemaan yhtä tiettyä konstruktiota. Vastaajille ei kerrottu, mihin virkkeiden ominaisuuteen heidän tulisi kiinnittää huomiota. Arvioiden jälkeen vastaajia pyydettiin järjestämään em. kymmenen tutkittavaa virkettä alenevaan järjestykseen kieliopillisimmasta epäkieliopillisimpaan. Tarkastellut konstruktiot näkyvät esimerkeissä 6-15.

(6) Verkko-opetusta rakentaessa kannattaa ensin määritellä sen tärkeimpiä perusteita eli oppimiskäsityksiä ja didaktiikkaa.

(7) Piirteen tehtävää on ollut vaikea luokitella kielioppia kirjoitettaessa. 
(8) Opettaessa äänteitä oppijoiden täytyy muistaa, että suomi on vokaalirikas kieli.

(9) Ammattikouluun tai yliopistoon siirtyessä oppilaan pitää edelleen saada tukea.

(10) EU:lla on todellakin maailman isoin kääntämis- ja tulkkauspalvelu kaikkien jäsenvaltioiden virallisten kielten ollessaan myös työkieliä.

(11) Lapsen toinen kieli on käytössä vain kotona ja vain tietyistä asioista keskustellessa.

(12) Ääntäessä ilmavirta pääsee kurkunpäästä esteettä ulos.

(13) Maija vastaa kysyttäessä, että hän asuisi kyllä mieluimmin Ahvenanmaalla.

(14) Komponenttianalyysia tehdessä valitaan ensin sanaryhmä tai sanapari.

(15) Kantakielestä nykysuomeen siirtyessä monta konsonanttia on kadonnut.

Tarkastelemme virkkeiden saamien oikeakielisyysarvioiden keskiarvoa ja sitä, miten yhdenmukaisia eri vastaajien arviot ovat ja missä määrin vastaajien esittämät virkkeiden kieliopillisuusjärjestykset poikkeavat toisistaan. Lisäksi tarkastelemme sitä, miten nämä vastaukset suhteutuvat konstruktion semanttisiin funktioihin eri osa-aineistoissa. Kyselyaineisto on kerätty Turun alueella kevään 2015 aikana 23:Ita suomea ensikielenään puhuvalta informantilta. Vastaajat olivat akateemisesti koulutettuja ja heistä 19 joko opiskeli tai työskenteli kielen parissa.

\section{Kyselytutkimus 2}

Kyselytutkimus 2 täydentää kyselytutkimusta 1 . Vastaajia pyydettiin järjestämään samat kymmenen virkettä (6-15) alenevaan järjestykseen kieliopillisimmasta epäkieliopillisimpaan. Tämän jälkeen vastaajille esitettiin samat virkkeet sekä aktiivi- että passiivimuodossa ja heitä pyydettiin arvioimaan virkkeiden oikeakielisyyttä viisiportaisella asteikolla niin, että (1) on yksiselitteisesti epäkieliopillinen ja (5) yksiselitteisesti kieliopillinen. Tämän jälkeen vastaajille esitettiin kustakin kymmenestä virkkeestä kolme eri parafraasia - 'sillä ehdolla, että, 'siitä syystä, että ja 'silloin, kun' - ja heitä pyydettiin arvioimaan nämä parafraasit viisiportaisella asteikolla niin, että (1) on yksiselitteisesti mahdoton tai järjetön ja (5) taas kaikin puolin mahdollinen ja järkevä. Lopuksi vastaajia pyydettiin kommentoimaan alkuperäisiä virkkeitä (6-15) sen kannalta, mikä niissä on kohdekielenvastaista. Kyselyaineisto on kerätty Turun alueella syksyn 2016 aikana, ja siihen vastasi 35 informanttia, joista 25 puhuu ensikielenään suomea ja 10 jotakin muuta kieltä. Kaikki vastaajat olivat akateemisesti koulutettuja, ja he opiskelivat kieliaineita. Ensikielenään jotakin muuta kuin suomea puhuvia vastaajia voidaan pitää korpusaineistomme S2-informanttien tavoin edistyneinä kielenoppijoina, sillä he suorittivat opintojaan suomen kielellä. 


\section{Tulokset}

\subsection{Inessiivisijaisen E-infinitivikonstruktion käytön määrällinen yleiskuva}

Tutkimus- ja vertailuaineistossa on kaikkiaan 355 inessiivisijaista E-infinitiivikonstruktiota, joista 242 (0,98 / 1000 sanetta) on aktiivissa ja 113 (0,52 / 1000 sanetta) passiivissa. Konstruktioista 129 on S2-aineistossa ja $226 S_{1}$-aineistossa. Taulukko 2 havainnollistaa esiintymämääriä sekä kuvaa $S_{2}$ - ja $S_{1}$-aineistojen välisten erojen tilastollista merkitsevyyttä sekä tekstilajeittain että yhtenä kokonaisuutena. Keskiarvot, mediaanit ja erojen tilastolliset merkitsevyydet on laskettu tekstikohtaisista esiintymämääristä siten, että kunkin tekstin esiintymät on normalisoitu tuhatta sanetta kohti.

Taulukko 2. Inessiivisijaisten infinitiivikonstruktioiden esiintyminen eri osa-aineistoissa.

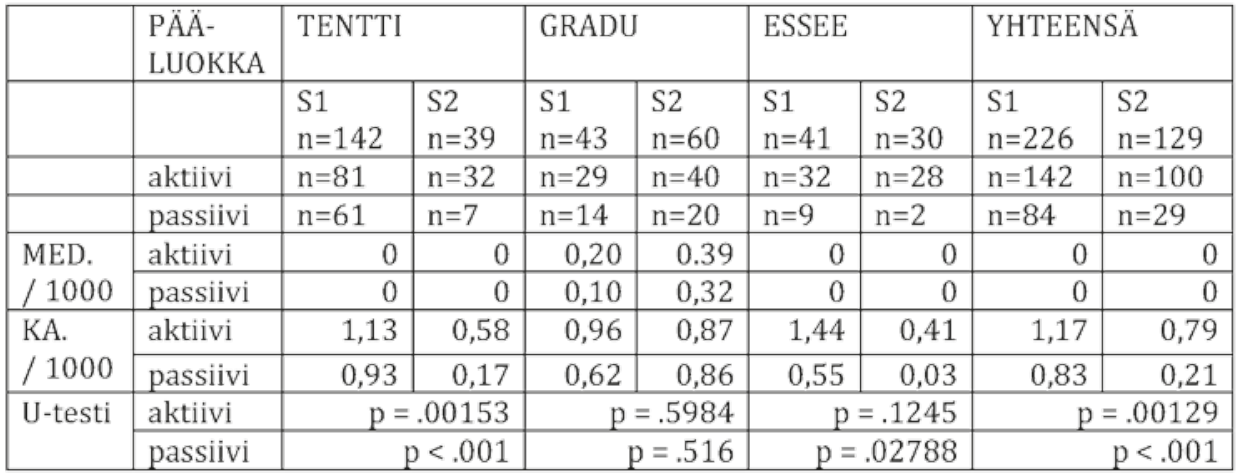

Kuten esiintymisfrekvenssien tunnusluvut osoittavat, konstruktio on verraten harvinainen - ja kuten mediaanit osoittavat, sitä esiintyy yli puolessa teksteistä vain graduissa. Aktiivi on passiivia yleisempi kaikissa osa-aineistoissa niin $S_{2}$ - kuin $S_{1}$-aineistoissakin. Konstruktiota käytetään tasaisimmin graduissa, kun taas muissa osa-aineistoissa vaihtelua on paljon. Erityisesti S2-aineistossa passiivikonstruktiota esiintyy lähes yksinomaan graduissa.

Aktiivi- ja passiivivariantti ovat kumpikin harvinaisempia $S_{2}$-aineistossa kuin $\mathrm{S}_{1}$-aineistossa, ja ero on molemmissa tapauksissa tilastollisesti merkitsevä ${ }^{4}$. S2- ja $S_{1}$-aineistojen välinen frekvenssiero on passiivikonstruktioiden osalta tilastollisesti merkitsevä tenteissä ja esseissä ja aktiivikonstruktioiden osalta ainoastaan tenteissä. Graduissa konstruktioita käytetään itse asiassa $S_{2}$-aineistossa $S_{1}$-aineistoa enemmän, joskaan ero ei ole tilastollisesti merkitsevä. Konstruktioiden käyttö ei siis erota yleisesti S1-kirjoittajia ja suomen taidoiltaan edistyneitä S2-kirjoittajia toisistaan, vaan ero perustuu tämän tutkimuksen aineiston valossa tekstilajiin - vaikka käsillä olevat tekstilajit ovatkin monin tavoin samankaltaisia.

4 Tilastollisen merkitsevyyden tulkinta on tässä artikkelissa tehty tasolla $\mathrm{p}<.05$. 


\subsection{Funktionaalinen ja leksikaalinen vaihtelu}

Aineiston 355 konstruktioesiintymästä noin $46 \%$ ilmaisee ensisijaisesti aikasuhdetta, noin $31 \%$ ehtosuhdetta ja noin $21 \%$ kausaalista vaikutussuhdetta. Loput esiintymät ovat merkitykseltään epäselviä. Koska epäselviä tapauksia on hyvin vähän, ne on jätetty määrällisen tarkastelun ulkopuolelle. Esimerkki 16 kuvaa esiintymää, jonka olemme tulkinneet ensisijaisesti aikasuhdetta kuvaavaksi, 17 kuvaa ehtosuhdetta ja 18 kausaalista vaikutussuhdetta.

(16) Tenttivastauksia voidaan pitää tutkimuksen kannalta havainnollisena materiaalina, koska ne on tuotettu kielen kannalta spontaanissa tilanteessa ilman apuvälineiden käytön mahdollisuuksia (vrt. Granger 2002, 8-9). Aineistoa on yhdeksältä informantilta ja sitä on yhteensä 2575 virkeriviä. Informantit ovat syntyneet ja asuneet osan elämästään muualla kuin Suomessa. Aineistoa kerättäessä kaikki informantit opiskelivat suomea Turun yliopistossa. Informanttien ensikielet ovat englanti, komi, liettua, ruotsi, tšekki, venäjä ja viro. (las2-vtto2vertoo2)

(17) Myös passiivilla ilmaistaan intentionaalisuutta: "Meille naurettiin", "Vene kaadettiin". Passiivi on aina elollistarkoitteinen eli passiivin "rajaama" epämääräinen joukko koostuu elollisista olennoista. Elollisista olennoista puhuttaessa on syytä pohtia tekojen intentionaalisuutta - lauseessa "Vene kaadettiin" kaatajan roolissa olevat henkilöt tai henkilö ovat harkinnan tuloksena päättänyt kaataa veneen. (las2-vtto1vert127)

(18) Luonnehtimisen kannalta on myös ollennaista onko kieli ylhäällä tai alhaalla . Diagrammassa näkee, että i, y ja ö ovat suppeita vokaaleja, eli kielenkärki niitä ääntäessa on ylhaalla. e, ö ja o ovat puolisuppeita ja ä, a laveita. (las2-14tto1teo1looo)

Funktiot jakautuvat aktiivi- ja passiivikonstruktioissa hyvin eri tavoin, sillä aktiivimuotoisista noin $58 \%(\mathrm{n}=142)$ ilmaisee aikasuhdetta, $12 \%(\mathrm{n}=28)$ ehtosuhdetta ja noin $28 \%(n=71)$ kausaalisuhdetta, kun taas passiivimuotoisista noin $19 \%(n=22)$ ilmaisee

Taulukko 3. Inessiivisijaisten E-infinitiivikonstruktioiden funktiot osa-aineistoittain.

\begin{tabular}{|l|l|r|r|r|r|r|r|r|r|}
\hline \multirow{2}{*}{ AIKA } & PÄÄ- & \multicolumn{2}{l|}{ TENTTI } & \multicolumn{2}{l|}{ GRADU } & \multicolumn{2}{l|}{ ESSEE } & \multicolumn{2}{l|}{ YHTEENSÄ } \\
\cline { 2 - 10 } & LUOKKA & S1 & S2 & S1 & S2 & S1 & S2 & S1 & S2 \\
\cline { 2 - 11 } & aktiivi & 35 & 20 & 17 & 30 & 18 & 20 & 70 & 70 \\
\cline { 2 - 11 } & passiivi & 11 & 2 & 5 & 2 & 2 & 0 & 18 & 4 \\
\hline \multirow{2}{*}{ KAUSAALI } & aktiivi & 26 & 7 & 8 & 8 & 11 & 8 & 45 & 23 \\
\cline { 2 - 11 } & passiivi & 5 & 1 & 0 & 1 & 1 & 0 & 6 & 2 \\
\hline \multirow{2}{*}{ EHTO } & aktiivi & 16 & 5 & 4 & 1 & 2 & 0 & 22 & 6 \\
\cline { 2 - 11 } & passiivi & 45 & 4 & 9 & 17 & 6 & 2 & 60 & 23 \\
\hline
\end{tabular}


aikasuhdetta, noin $73 \%(\mathrm{n}=83)$ ehtosuhdetta ja noin $7 \%(\mathrm{n}=8)$ kausaalisuhdetta. Taulukko 3 kuvaa näiden funktioiden esiintymistä osa-aineistoittain.

Aktiivikonstruktio on passiivivarianttia yleisempi kahden teon ajallista suhdetta tai tekojen keskinäistä vaikutussuhdetta ilmaisemassa, kun taas passiivi on aktiivia yleisempi tekojen välistä ehtosuhdetta ilmaisemassa. Aktiivin tilastollisesti merkitsevä käyttöero tenteissä toistuu kaikissa konstruktion funktioissa niin, että ero on suhteellisesti suurin kausaali- ja ehtosuhteissa. Kun verrataan ylipäätään $S_{2}$ - ja $S_{1}$-aineistoa toisiinsa, nähdään, että konstruktion ensisijainen funktio aikasuhteen ilmaisijana on selvästi yleisempi S2-aineistossa ( $57 \%$ kaikista esiintymistä) kuin S1-aineistossa (39\% kaikista esiintymistä). Passiivien tilastollisesti merkitsevä käyttöero tenteissä heijastuu niin ikään kaikissa konstruktion funktioissa, joskin se on selvin konstruktion yleisimmässä funktiossa - ehtosuhteen ilmaisijana. Passiivikonstruktion osalta $S_{2}$ - ja $S_{1}$-aineistojen välinen käyttöero näyttää siis yhtäältä olevan tekstilajikohtainen mutta toisaalta myös merkityskohtainen - passiivia käytetään ilmaisemaan nimenomaan ehtosuhdetta, mikä puolestaan on tyypillistä tenteille.

Aktiivi- ja passiivikonstruktioiden välisen suhteen kannalta on mielenkiintoista, että S2-aineistossa kunkin funktion yleisempi muoto kattaa myös suuremman osan kaikista esiintymistä. Näin on sekä kussakin tekstilajikohtaisessa osa-aineistossa että koko aineistossa. Esimerkiksi kaikista aikasuhdetta ilmaisevista konstruktioista suurempi osa on aktiivisia ja $S_{2}$-aineistossa osuus on suhteellisesti suurempi ( 71 aktiivia ja 4 passiivia) kuin S1-aineistossa (71 aktiivia ja 18 passiivia). Vastaavasti gradujen ehtosuhdetta ilmaisevista

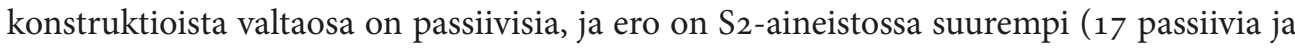
1 aktiivi) kuin $S_{1}$-aineistossa (9 passiivia ja 4 aktiivia). Ainoa poikkeus ovat ehtosuhdetta kuvaavat konstruktiot tenteissä, joissa myös kokonaismäärä on S2-aineistossa hyvin pieni. Konstruktioiden prototyyppinen käyttö on siis $S_{2}$-aineistossa yleisempää ja tekstilajikohtainen funktionaalinen vaihtelu vähäisempää. Tenteissä havaittava passiivisten ehtoa ilmaisevien konstruktioiden poikkeava jakauma ei täysin sovi tulkintaan, mutta poikkeus saattaa johtua siitä, että ehtoa ilmaiseva funktio on ylipäätään vasta kehkeytymässä osaksi S2-kirjoittajien spontaania kielirepertoaaria.

Tämän aineiston valossa on mahdotonta sanoa, minkälainen näiden kahden muuttujan vaikutussuhde on luonteeltaan tai suunnaltaan. Onko kyseessä siis edistyneiden kielenoppijoiden tekstilajikohtaisen kielenkäytön oppimiseen liittyvä ilmiö, joka näkyy tekstilajille tyypillisen funktion käytössä, vai konstruktion tietyn funktion oppimiseen liittyvä ilmiö, joka näkyy sille tyypillisessä tekstilajissa? Selvää silti on, että yhden tekijän huomioon ottaminen ilman toista ei tee oikeutta tarkasteltavalle ilmiölle. Tekstien tuottamistilanteen kannalta on kiintoisaa, että erot heijastuvat juuri tenteissä, joka on tarkastelluista tekstilajeista kaikkein spontaanein, vähiten suunniteltu ja yksityisin. Funktioiden kannalta on puolestaan kiintoisaa, että erot ovat selvempiä konstruktion niissä funktioissa, jotka eivät vastaa yksinomaan sen ensisijaista funktiota ajallisten suhteiden ilmaisijana.

Konstruktion leksikaalinen vaihtelu osoittaa, että konstruktio on selvästi produktiivinen niin $S_{2}$ - kuin $S_{1}$-aineistossakin. S2-aineiston 129 esiintymässä on 57 eri verbiä ja 
S1-aineiston 226 esiintymässä 95 eri verbiä. Toisin sanoen S2-aineistossa konstruktion absoluuttisen esiintymäfrekvenssin ja sen leksikaalista vaihtelua kuvaavan tyyppifrekvenssin suhde on 57/129 $\approx 0.44$, kun taas $S_{1}$-aineistossa vastaava suhde on 95/226 $\approx 0.42$. Konstruktion suhteellisessa skemaattisuudessa ei toisin sanoen ole eroa osa-aineistojen välillä.

Konstruktion yleisimpien verbien vertailu $S_{2}$ - ja $S_{1}$-aineistossa osoittaa, että joukossa on yksiselitteisesti aikasuhdetta kuvaavia verbejä, kuten kulua, mennä ja kehittyä, aikaja ehtosuhdetta ilmaisemaan käytettyjä kommunikaatioverbejä, kuten puhua, arvioida ja lukea, ja geneerisiä, yksinomaan kontekstin perusteella tulkintansa saavia verbejä, kuten olla. Yleisimpien lekseemien määrä näkyy taulukosta 4.

Taulukko 4. Inessiivisijaisten E-infinitiivikonstruktioiden yleisimmät lekseemit osaaineistoittain. Taulukossa on kunkin osa-aineiston sellaiset kolme yleisintä lekseemiryhmää (rivit 1, 2 ja 3), joissa esiintymiä on enemmän kuin yksi.

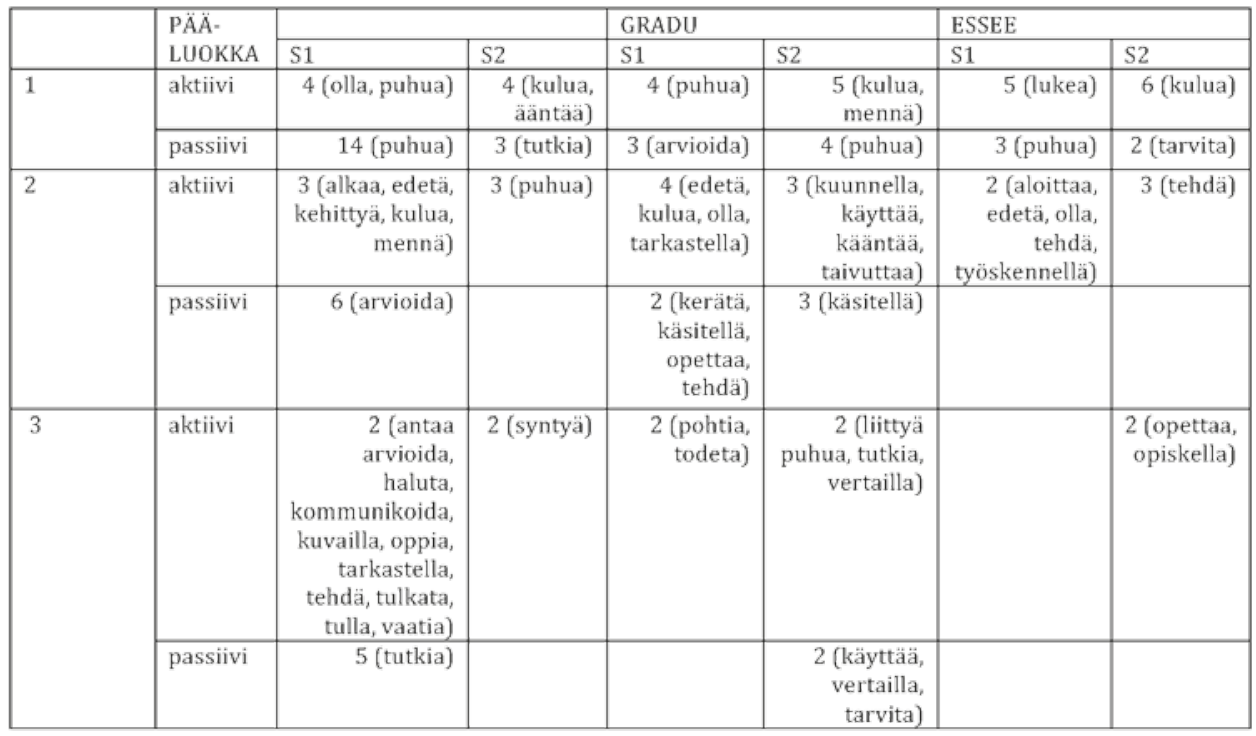

Leksikaalisesta vaihtelusta heijastuu sama tendenssi kuin funktionaalisesta vaihtelusta. Aikasuhdetta ilmaisevat verbit ovat suhteessa yleisempiä S2-aineistossa, kun taas S1-aineistossa korostuvat niin aika- kuin ehtosuhdettakin ilmaisemaan käytetyt kommunikaatioverbit, kuten puhua, arvioida ja lukea. Distinktiivisen kollekseemianalyysin avulla tehty $S_{2}$ - ja $S_{1}$-aineiston leksikaalisen vaihtelun tarkastelu tukee tätä tulkintaa. Analyysin tulokset näkyvät taulukosta 5 . 
Taulukko 5. Ne inessiivisijaisen E-infinitiivikonstruktion verbit, jotka erottavat distinktiivisen kollekseemianalyysin perusteella parhaiten S2- ja S1-aineistoja toisistaan.

\begin{tabular}{|l|l|l|l|}
\hline KOLLEKSEEMI & S1 & S2 & DISTINKTIIVISYYS \\
\hline kulua & $7(14,01)$ & $15(7,99)$ & 0.002263461 \\
\hline arvioida & $12(7,64)$ & $0(4,36)$ & 0.004965944 \\
\hline
\end{tabular}

Verbin kulua käyttö erottaa osa-aineistoja toisistaan vahvimmin niin, että se esiintyy S2-aineistossa likimain kaksi kertaa niin usein (15 esiintymää) kuin tasainen jakauma (n. 8 esiintymää) antaisi olettaa ja $S_{1}$-aineistossa vastaavasti harvemmin (7 esiintymää vs. n. 14 esiintymää). Vastaavasti verbi arvioida esiintyy $S_{1}$-aineistossa selvästi tasaista jakaumaa yleisemmin (12 esiintymää vs. n. 8 esiintymää) ja $S_{2}$-aineistossa harvemmin (o esiintymää vs. n. 4 esiintymää). Leksikaalisen vaihtelun tarkastelu siis tukee aiempaa tulkintaa siitä, että S2-aineiston E-infinitiivikonstruktioissa on vähemmän vaihtelua ja että konstruktion prototyyppiset merkitykset kattavat suuremman osan kaikista esiintymistä.

\subsection{Oikeakielisyysarvioinnit kyselytutkimuksissa}

E-infinitiivikonstruktioiden oikeakielisyysarvioissa nousee esiin muutamia varteenotettavia seikkoja. Taulukossa 6 esimerkit on järjestetty hyväksyttävimmästä vähiten hyväksyttävään niiden järjestelytehtävässä saamien arvioiden keskiarvojen perusteella. Taulukko havainnollistaa siis oikeakielisyysarvioiden keskiarvoja (kyselytutkimus 1) sekä järjestelytehtävässä saatujen vastausten keskiarvoja (kyselytutkimus 1 ja 2).

Tarkastellut kymmenen esimerkkiä jakautuvat arvioiden mukaan kolmeen ryhmään. Jakauma toistuu sekä esimerkkikohtaisissa oikeakielisyysarvioissa että $\mathrm{S}_{1}$-arvioijien listoissa esimerkkien suhteellisesta oikeakielisyydestä. Yksi esimerkki (taulukon 6 rivi 1) on luokiteltu selvästi muita oikeakielisemmäksi, ja se erottuu myös oikeakielisyysjärjestyslistauksessa muista esimerkeistä. Toisen ryhmän muodostavat kuusi muuta esimerkkiä (taulukon 6 rivit $2-7$ ), joiden arviot ovat keskenään samankaltaisia ja joiden keskinäinen järjestykseen perustuva luokitus tosin vaihtelee huomattavasti ja erottuu samalla muista esimerkeistä. Kolmannen ryhmän esimerkit (taulukon 6 rivit 8-10) on puolestaan arvioitu selvästi muita vähemmän oikeakielisiksi, ja niiden arviot ovat keskenään samankaltaisia. ${ }^{5}$ Nämä kolme ryhmää hahmottuvat taulukon riviä 7 lukuun ottamatta samankaltaisiksi sekä kyselytutkimusten 1 ja 2 S1-aineistossa, kun taas kyselytutkimuksessa 2 kerätyssä $S_{2}$-aineistossa arvioitujen virkkeiden keskinäinen järjestys on hyvin erilainen eikä se noudata edellä kuvattua ryhmittymistä.

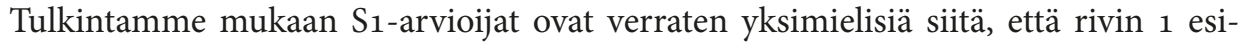
merkki on kohdekielenmukainen, rivien 2-7 esimerkeissä on jotain yllättävää mutta ne

5 Kuten nämä arviot osoittavat, ensikielisetkään arvioijat eivät koskaan ole täysin yksimielisiä. Nyt käsillä olevan konstruktion käytössä ja sen hallinnassa on vaihtelua ja horjuntaa myös ensikielisten kielenkäyttäjien piirissä (Kurki 2016). 
Taulukko 6. Kymmenen E-infinitiivikonstruktion oikeakielisyysarvioinnit.

\begin{tabular}{|c|c|c|c|c|c|}
\hline & & \multicolumn{2}{|c|}{ KYSELYTUTKIMUS 1 (S1) } & \multicolumn{2}{|c|}{ KYSELYTUTKIMUS 2 (S1 ja S2) } \\
\hline & \multirow[t]{2}{*}{ ESIMERKKI } & \multirow{2}{*}{$\begin{array}{l}\text { ARVION } \\
\text { KA. } \\
\text { (arviot } \\
1-5 \text { ) }\end{array}$} & \multirow{2}{*}{$\begin{array}{l}\text { JÄRJESTYKSEN } \\
\text { KA. } \\
\text { (järjestys } \\
1-10 \text { ) }\end{array}$} & S1 & $\mathrm{S} 2$ \\
\hline & & & & $\begin{array}{l}\text { JÄRJESTYKSEN } \\
\text { KA. } \\
\text { (järjestys } 1 \text { - } \\
10 \text { ) }\end{array}$ & $\begin{array}{l}\text { JÄRJESTYKSEN } \\
\text { KA. } \\
\text { (järjestys } 1 \text { - } \\
10 \text { ) }\end{array}$ \\
\hline 1 & $\begin{array}{l}\text { Piirteen tehtävää on ollut } \\
\text { vaikea luokitella kielioppia } \\
\text { kirjoitettaessa. }\end{array}$ & 4.6 & $2.17=1$ & $2.68=1$ & $5.3=8$ \\
\hline 2 & $\begin{array}{l}\text { Lapsen toinen kieli on } \\
\text { käytössä vain kotona ja } \\
\text { vain tietyistä asioista } \\
\text { keskustellessa. }\end{array}$ & 3.9 & $3.52=2$ & $4.44=5$ & $4.6=6$ \\
\hline 3 & $\begin{array}{l}\text { Komponenttianalyysia } \\
\text { tehdessä valitaan ensin } \\
\text { sanaryhmä tai sanapari. }\end{array}$ & 4.0 & $3.70=3$ & $4.28=4$ & $3.5=2$ \\
\hline 4 & $\begin{array}{l}\text { Ammattikouluun tai } \\
\text { yliopistoon siirtyessä } \\
\text { oppilaan pitää edelleen } \\
\text { saada tukea. }\end{array}$ & 3.9 & $4.09=4$ & $4.44=5$ & $4.3=5$ \\
\hline 5 & $\begin{array}{l}\text { Verkko-opetusta } \\
\text { rakentaessa kannattaa } \\
\text { ensin määritellä sen } \\
\text { tärkeimpiä perusteita eli } \\
\text { oppimiskäsityksiä ja } \\
\text { didaktiikkaa. }\end{array}$ & 3.6 & $4.35=5$ & $4.04=2$ & $2.1=1$ \\
\hline 6 & $\begin{array}{l}\text { Ääntäessä ilmavirta } \\
\text { pääsee kurkunpäästä } \\
\text { esteettä ulos. }\end{array}$ & 3.7 & $4.39=6$ & $4.08=3$ & $4.2=4$ \\
\hline 7 & $\begin{array}{l}\text { Maija vastaa kysyttäessä, } \\
\text { että hän asuisi kyllä } \\
\text { mieluimmin } \\
\text { Ahvenanmaalla. }\end{array}$ & 3.9 & $4.91=7$ & $5.48=7$ & $7.2=10$ \\
\hline 8 & $\begin{array}{l}\text { Kantakielestä } \\
\text { nykysuomeen siirtyessä } \\
\text { monta konsonanttia on } \\
\text { kadonnut. }\end{array}$ & 2.9 & $6.26=8$ & $5.96=8$ & $4=3$ \\
\hline 9 & $\begin{array}{l}\text { Opettaessa äänteitä } \\
\text { oppijoiden täytyy muistaa, } \\
\text { että suomi on vokaalirikas } \\
\text { kieli. }\end{array}$ & 2.6 & $6.48=9$ & $6.88=9$ & $4.9=7$ \\
\hline 10 & $\begin{array}{l}\text { EU:lla on todellakin } \\
\text { maailman isoin } \\
\text { kääntämis- ja } \\
\text { tulkkauspalvelu kaikkien } \\
\text { jäsenvaltioiden virallisten } \\
\text { kielten ollessaan myös } \\
\text { työkieliä. }\end{array}$ & 2.7 & $6.65=10$ & $7.2=10$ & $6=9$ \\
\hline
\end{tabular}


koetaan kuitenkin melko oikeakielisiksi, kun taas rivien 8-10 esimerkeissä on jotain selvästi kohdekielenvastaista. Kyselytutkimuksen 2 tulokset paljastavat lisäksi, että rivin 7 esimerkki on koettu kohdekielenvastaiseksi ennen kaikkea sanajärjestyksen ja mieluimmin-sanan vuoksi, ei infinitiivin takia. Virkettä 7 sekä $S_{1}$ - että $S_{2}$-arvioijat pitivät selvästi kohdekielenvastaisena. ${ }^{6}$ Muuten $S_{2}$-arvioijien vastauksista samat kolme ryhmää eivät kuitenkaan nouse esiin eli S2-vastaajat eivät jaa samaa käsitystä virkkeiden kohdekielenmukaisuudesta.

Ensikieliset arvioijat kokevat passiivikonstruktion aktiivikonstruktiota kohdekielenmukaisemmaksi kaikissa tarkastelluissa virkkeissä taulukon 6 rivin 10 esimerkkiä lukuun ottamatta - passiivimuotojen arvioiden keskiarvo on kussakin tapauksessa viisiportaisella asteikolla yli 3.8. Aktiivimuodoista kohdekielenmukaisimmaksi on arvioitu rivin 6 Ääntäessä ilmavirta pääsee kurkunpäästä esteettä ulos, ja sen saamien arvioiden keskiarvo on 3.01. Rivin 10 esimerkkivirke on todettu selvästi kohdekielenvastaiseksi niin aktiivikuin passiivimuotoisenakin. Suomea toisena kielenä puhuvien vastauksista ei nouse esiin mitään selvää tendenssiä - puolessa lauseista (taulukon 6 rivit 2, 5, 6, 9, 10) aktiivi- ja passiivimuotoinen lause on koettu keskimäärin yhtä kohdekielenmukaiseksi, kolmessa tapauksessa (taulukon rivit 3, 4, 8) aktiivimuoto on koettu selvästi passiivimuotoa kohdekielenmukaisemmaksi ja kahdessa tapauksessa (rivit 1 ja 7 ) passiivimuoto on koettu aktiivimuotoa kohdekielenmukaisemmaksi.

Kyselytutkimuksen 2 S1-vastaajat ovat verraten yksimielisiä siitä, mikä kussakin lauseessa on epäodotuksenmukaista tai kohdekielenvastaista. Tarkastelluista kymmenestä virkkeestä kuudessa (taulukon 7 rivit 2, 3, 5, 6, 8 ja 9) ensikieliset arvioijat kokevat ongelmaksi E-infinitiivin pääluokan tai ainakin E-infinitiivin ylipäätään. Kahdessa tapauksessa (taulukon 7 rivit 4 ja 10) ongelman katsotaan liittyvän omistusliitteeseen ja kahdessa (taulukon 7 rivit 1 ja 7 ) ei valtaosan mielestä ole mitään kohdekielenvastaista. Useassa tapauksessa iso osa $S_{1}$-arvioijista ei ehdota yhtään korjausta huolimatta siitä, että arvioinneissa virkkeet arvioitiin jollakin tavalla kohdekielenvastaisiksi. S2-arvioijat esittävät vielä vähemmän korjausehdotuksia; valtaosa heistä ei tarjoa minkäänlaisia korjauksia virkkeisiin. Kun nämä arvioijat ehdottavat korjausta, se kohdistuu useimmiten infinitiiviin: he esimerkiksi ehdottavat sijalle jotakin toista infinitiivikonstruktiota, kuten MA-infinitiiviä. Omistusliitteen käyttöön liittyviä korjausehdotuksia ei ole kuin yksi kappale.

Sekä esimerkkikohtaiset että järjestykseen perustuvat arviot muodostavat samankaltaisen ryhmityksen, joten ensikieliset kielenkäyttäjät kokevat esimerkkilauseiden kieliopillisuuden keskenään samalla tavalla. Tarkastelemme seuraavaksi kolmea vähiten kohdekielisenä pidettyä esimerkkiä yksityiskohtaisemmin.

6 Kielenhuollonoppaissa käsitellään essA-infinitiivikonstruktiota melko vähän (ks. kuitenkin luku 2). Aktiivi- ja passiivikonstruktion hyväksyttävyyseroista olisi tärkeätä tehdä ensikielisille kyselytutkimus vain ensikielisten tekstilauseista tai konstruoiduista tekstilauseista, joissa olisi sumea raja konstruktioiden käytön välillä. Oikeakielisyyttä ei aina voi ratkaista ilman tietoa kirjoittajan omista intentioista. Myös nollapersoonan ja ilmipassiivin taustalla olevien tekijöiden tulkinta aiheuttaa sumeutta. Näitä kysymyksiä ei voi kuitenkaan pohtia enempää tässä artikkelissa. 
Taulukko 7. Kymmenen E-infinitiivikonstruktion korjausehdotukset.

\begin{tabular}{|c|c|c|c|c|c|c|c|c|c|c|c|}
\hline & & \multicolumn{2}{|c|}{$\begin{array}{l}\text { INFINITIIVI+ } \\
\text { PASSIIVI }\end{array}$} & \multicolumn{2}{|c|}{ INFINITIIVI } & \multicolumn{2}{|c|}{$\begin{array}{l}\text { INFINITIIVI + } \\
\text { OMISTUSLIITE }\end{array}$} & \multicolumn{2}{|l|}{ MUU } & \multicolumn{2}{|c|}{ EI MITÄÄN } \\
\hline & ESIMERKKI & S1 & S2 & S1 & S2 & S1 & S2 & S1 & S2 & S1 & S2 \\
\hline 1 & $\begin{array}{l}\text { Piirteen tehtävää on ollut } \\
\text { vaikea luokitella kielioppia } \\
\text { kirjoitettaessa. }\end{array}$ & 1 & 2 & 1 & 1 & 0 & 0 & 2 & 1 & 21 & 6 \\
\hline 2 & $\begin{array}{l}\text { Lapsen toinen kieli on } \\
\text { käytössä vain kotona ja vain } \\
\text { tietyistä asioista } \\
\text { keskustellessa. }\end{array}$ & 16 & 0 & 3 & 2 & 0 & 0 & 0 & 1 & 6 & 7 \\
\hline 3 & $\begin{array}{l}\text { Komponenttianalyysia } \\
\text { tehdessä valitaan ensin } \\
\text { sanaryhmä tai sanapari. }\end{array}$ & 12 & 3 & 1 & 1 & 0 & 0 & 0 & 0 & 12 & 6 \\
\hline 4 & $\begin{array}{l}\text { Ammattikouluun tai } \\
\text { yliopistoon siirtyessä } \\
\text { oppilaan pitää edelleen } \\
\text { saada tukea. }\end{array}$ & $5 / 2$ & 0 & 1 & 0 & $14 / 11$ & 1 & 0 & 0 & 8 & 9 \\
\hline 5 & $\begin{array}{l}\text { Verkko-opetusta } \\
\text { rakentaessa kannattaa } \\
\text { ensin määritellä sen } \\
\text { tärkeimpiä perusteita eli } \\
\text { oppimiskäsityksiä ja } \\
\text { didaktiikkaa. }\end{array}$ & 15 & 0 & 3 & 1 & 0 & 0 & 0 & 1 & 7 & 8 \\
\hline 6 & $\begin{array}{l}\text { Aäntäessä ilmavirta pääsee } \\
\text { kurkunpäästä esteettä ulos. }\end{array}$ & 12 & 2 & 1 & 1 & 0 & 0 & 1 & 1 & 11 & 6 \\
\hline 7 & $\begin{array}{l}\text { Maija vastaa kysyttäessä, } \\
\text { että hän asuisi kyllä } \\
\text { mieluimmin } \\
\text { Ahvenanmaalla. }\end{array}$ & 1 & 1 & 0 & 0 & 0 & 0 & 5 & 2 & 19 & 7 \\
\hline 8 & $\begin{array}{l}\text { Kantakielestä nykysuomeen } \\
\text { siirtyessä monta } \\
\text { konsonanttia on kadonnut. }\end{array}$ & 17 & 2 & 4 & 2 & 0 & 0 & 1 & 1 & 3 & 5 \\
\hline 9 & $\begin{array}{l}\text { Opettaessa äänteitä } \\
\text { oppijoiden täytyy muistaa, } \\
\text { että suomi on vokaalirikas } \\
\text { kieli. }\end{array}$ & 13 & 0 & 6 & 1 & 0 & 0 & 3 & 1 & 3 & 6 \\
\hline 10 & $\begin{array}{l}\text { EU:lla on todellakin } \\
\text { maailman isoin kääntämis- } \\
\text { ja tulkkauspalvelu kaikkien } \\
\text { jäsenvaltioiden virallisten } \\
\text { kielten ollessaan myös } \\
\text { työkieliä. }\end{array}$ & 1 & 0 & 3 & 0 & 12 & 0 & 7 & 3 & 2 & 7 \\
\hline
\end{tabular}

(19) Kantakielestä nykysuomeen siirtyessä monta konsonanttia on kadonnut. (las2-2otto1teo1)

(20) Opettaessa äänteitä oppijoiden täytyy muistaa, että suomi on vokaalirikas kieli. (las2-21tto1teo7)

Esimerkit 19 ja 20 (taulukon 6 rivit 8 ja 9) ovat S2-aineiston tenteistä. Niin oman arviomme kuin ensikielisten arvioijienkin mukaan esimerkkien kohdekielenvastaisuus liittyy ainakin pääosin konstruktion pääluokkaan - odotuksenmukainen muoto olisi passiivinen variantti. Konstruktiot voitaneen tulkita funktion kannalta kahdella tavalla. Aikasuhdetulkinta korostaisi konkreettista ajallista samanaikaisuutta tai lähekkäisyyttä 
- esimerkissä 19 kehityksen etenemistä kantakielestä nykysuomeen ja esimerkissä 20 opettamisen ja muistamisen samanaikaisuutta. Toinen tulkintavaihtoehto on nähdä konstruktiot ehtosuhteen ilmaisijoina. Esimerkki 19 ilmaisisi sitä ehtoa, että tarkastelun fokus siirretään kantakielestä nykysuomeen. Esimerkissä 20 muistamisen ehtona olisi opetustilanne. Esimerkin 19 kohdalla kaikki arvioijat pitivät ehtosuhde- ja aikasuhde-parafraaseja suunnilleen yhtä järkevinä ( $S_{1}$ : ehtosuhde 3.3, kausaalisuhde1.2 ja aikasuhde 3.6; $S_{2}$ : ehtosuhde 3.1, kausaalisuhde 1.7 ja aikasuhde $3.6^{7}$ ) ja esimerkin 20 kohdalla aikasuhdeparafraasi arvioitiin järkevimmäksi, joskin myös ehtosuhde koettiin täysin mahdolliseksi (S1: ehtosuhde: 3.6, kausaalisuhde 1.3 ja aikasuhde 4.6; S2: ehtosuhde 3.1, kausaalisuhde 2.0 ja aikasuhde 3.4). Ehtoa ilmaisevat konstruktiot lankeavat tenttivastausten osa-aineistossa ryhmään, jonka edustajia on S2-aineistossa vähän; viisi aktiivimuotoista ja neljä passiivimuotoista esiintymää. Ero $S_{1}$-aineistoon on erityisen selvä passiivimuotoisten ehtoa ilmaisevien konstruktioiden osalta, sillä niitä on $S_{1}$-aineiston tenttivastauksissa 45 esiintymää (aktiivimuotoisia on 16 esiintymää). Esimerkissä 20 on myös mahdollista, että kyseessä on oppia-verbin passiivin ja luonteeltaan kausatiivisen opettaa-verbin aktiivin yhteensulauma. Tulkinnan epäselvyys saattaakin olla yksi keskeinen tekijä oikeakielisyysarvioinnin kannalta ilmaistavan funktion ja sen tyypillisen muodon ristiriidan ohella.

(21) EU:lla on todellakin maailman isoin kääntämis- ja tulkkauspalvelu kaikkien jäsenvaltioiden virallisten kielten ollessaan myös työkieliä. (las235 tto1teo2)

Esimerkin 21 konstruktion merkitys on kaukana aikasuhdetulkinnasta, ja se lähenee luonteeltaan kausaalisuhteen ilmaisemista niin, että esimerkin parafraasi olisi 'EU:lla on todellakin maailman isoin kääntämis- ja tulkkauspalvelu siitä syystä, että kaikkien jäsenvaltioiden viralliset kielet ovat myös työkieliä' ( $S_{1}$ : ehtosuhde 2.0, kausaalisuhde 4.4, aikasuhde 2.9; S2: ehtosuhde 2.7, kausaalisuhde 4.1, aikasuhde 2.7). Esimerkin selkein kohdekielenvastainen piirre on possessiivisuffiksin käyttö tapauksessa, jossa viittauskohde ei ole ilmaistavissa persoonapronominilla (VISK \$ 1294). E-infinitiivikonstruktion ja kirjoitetun kielen substantiiveille ominaisen omistusliitteen käytön voineekin helposti nähdä oppimisen kannalta kompleksisena piirteenä, jossa ilmenee horjuntaa vielä edistyneessäkin oppijankielessä (Siitonen-Mizuno 2010). Toisaalta esimerkki 21 ilmaisee semanttisen kausaalisuhteen lisäksi myös eräänlaista tekstuaalista rinnastussuhdetta (VISK \$545), mikä näyttää ainakin tämän aineiston valossa hyvin harvinaiselta. Tapaus voidaankin nähdä esimerkkinä samanaikaisesta useiden kielellisesti epätyypillisten piirteiden lankeamisesta yhteen, minkä on esitetty lisäävän kohdekielenvastaisten ilmausten mahdollisuutta (ks. Ivaska 2011). Esimerkistä 21 voidaan ajatella, että kompleksisen ja verraten harvinaisen konstruktion (-essA-konstruktio) epätyypillisen merkityksen (kausaalisuhde) kanssa lankeaa yhteen kielenpiirre (possessiivisuffiksi), jonka tyypillinen käyttö rajautuu

7 Myös näissä arvioissa käytössä oli viisiportainen asteikko, jossa (5) vastaa täysin järkeenkäypää ilmausta ja (1) täysin järjetöntä ilmausta. 
tiettyihin yhteyksiin (kirjoitettu kieli) ja jota käytetään tyypillisesti jonkin toisen sanaluokan (substantiivi) yhteydessä.

\section{Päätelmät, tulkinnat ja yhteenveto}

Analyysin perusteella vastaamme tutkimuskysymyksiimme seuraavasti: Inessiivisijaisen E-infinitiivikonstruktion käyttö on kaikkiaan melko harvinaista - konstruktiota esiintyy alle puolessa tutkituista teksteistä. Konstruktion aktiivimuotoinen variantti on yleisempi niin $S_{2}$ - kuin $S_{1}$-aineistossakin, joskin $S_{2}$-aineistossa ero on $S_{1}$-aineistoa suurempi. Tutkituista tekstilajeista konstruktion käyttö erottaa $S_{2}$ - ja $S_{1}$-aineistoja toisistaan tilastollisesti merkitsevästi tenteissä sekä aktiivi- että passiivikonstruktioiden osalta ja esseissä passiivikonstruktioiden osalta. Kaikissa näissä tapauksissa konstruktio on yleisempi S1-aineistossa. Vajaa puolet konstruktioista ilmaisee ensisijaisesti aikasuhdetta, noin kolmannes ehtosuhdetta ja noin viidennes kausaalista vaikutussuhdetta. Nämä funktiot jakautuvat aktiivi- ja passiivikonstruktioihin siten, että aikasuhde on selvästi yleisin merkitys aktiivikonstruktioille, kun taas passiivikonstruktioista valtaosa ilmaisee ehtosuhdetta. Tekstilajien välisistä eroista selvin on se, että ehtosuhteen ilmaiseminen on tyypillistä erityisesti tenteissä. $S_{2}$ - ja $S_{1}$-aineistot eroavat toisistaan ennen kaikkea siten, että $S_{2}$-aineistossa konstruktion tyypillisin merkitys - aktiivisissa tapauksissa aikasuhde ja passiivisissa tapauksissa ehtosuhde - kattaa suuremman osan konstruktion kaikista esiintymistä. Leksikaalinen variaatio tukee tätä tulkintaa, sillä ensisijaisesti aikasuhdetta ilmaisevat verbit ovat suhteellisesti yleisempiä S2-aineistossa, kun taas merkitykseltään yleisemmät verbit ovat suhteellisesti yleisempiä $S_{1}$-aineistossa. Tarkasteltujen konstruktioiden merkitystulkinnat ovat väistämättä subjektiivisia ja riippuvat käytetyistä kriteereistä (tämän tutkimuksen kriteereistä ks. luku 3), kuten myös kyselytutkimuksemme tulokset osoittavat. Toisenlaisten kriteerien käyttö varmasti muuttaisi tuloksia tavalla tai toisella. Uskomme silti, että havaintomme funktion ja pääluokan korrelaatiosta samoin kuin tyypillisimpien funktioiden yleisyydestä ovat päteviä.

S1-puhujien oikeakielisyysarviot osoittavat, että he tunnistavat edistyneiden S2-oppijoiden tuottamien konstruktioiden poikkeamisen kohdekielestä ja kokevat oikeakielisyyden melko samalla tavalla. Kymmenestä tarkastellusta esimerkistä nousee esiin kohdekielisyyden kannalta kolme erilaista ryhmää: yksi esimerkki koettiin lähes yksiselitteisesti kohdekielenmukaiseksi, kuusi esimerkkiä vaikutti osin kohdekielenvastaisilta ja kolme esimerkkiä koettiin selvästi kohdekielenvastaisiksi. S2-arvioijien vastauksista nämä ryhmät eivät nouse esiin. S1-arvioijat olivat hyvin yksimielisiä siitä, että ongelmat liittyivät infinitiivin pääluokkaan tai joissakin tapauksissa omistusliitteen käyttöön, kun suomea toisena kielenä oppineiden arvioijien vastauksista tämä ei näy. On lisäksi merkillepantavaa, että kaikissa kolmessa kohdekielenvastaiseksi koetussa esimerkissä konstruktio ilmaisee jotakin muuta kuin sen ensisijaista, aikasuhdetta kuvaavaa merkitystä tai konstruktion merkitys on monitulkintainen. Emme ole tarkastelleet tulosten tilastollista merkitsevyyttä, sillä tällainen tarkastelu ei nähdäksemme merkittävästi vahvistaisi jo nyt 
melko selviä havaittuja tendenssejä. S2-arvioijien vastauksia on sitä paitsi liian vähän tällaisen tarkastelun oikeuttamiseen.

Inessiivisijaisen E-infinitiivikonstruktion käytön kuvaamisen lisäksi tuloksilla on yleisempää merkitystä toisen kielen oppimisen tutkimukselle. Käytön suhteellinen vähäisyys ja laadullisesti kohdekielenvastaiset konstruktiot viittaavat osittaiseen omaksumiseen tai käynnissä olevaan omaksumisprosessiin. Kuten useat niin sanottua DEMfad-mallia (mallista ks. Martin ym. 2010) soveltavat tutkimukset osoittavat, kohdekielenmukaista käyttöä edeltää lähes aina käytön frekvenssin kasvu (ks. esim. Kajander 2013; Seilonen 2013; Siivelt-Mustonen 2013). Prototyyppisten merkitysten korostuminen S2-aineistossa vastaa aiemmassa tutkimuksessa (ks. esim. Lauranto 1997; Martin ym. 2010; Mustonen 2015) havaittua konkreettisten merkitysten vähittäistä vaihtelun kasvua ja abstraktistumista. Erot funktionaalisessa distribuutiossa kuvannevat tällaista osittaista oppimista, sillä $\mathrm{S}_{2}$-aineistossa korostuvat $\mathrm{S}_{1}$-aineistoa enemmän konstruktion eri varianttien prototyyppisemmät muodot ja oikeakielisyysarvioissa esiin nousseet kohdekielenvastaiset muodot ilmaisevat kaikki jotain muuta kuin konstruktion tyypillisintä merkitystä.

Metodologisesta näkökulmasta tutkimuksemme osoittaa, että oppijansuomen erityispiirteitä tarkasteltaessa on pyrittävä mahdollisuuksien mukaan huomioimaan oppimisprosessin dynaamisuus ja monitahoisuus (ks. esim. Larsen-Freeman 1997; Larsen-Freeman-Cameron 2008) ja prosessin monet muuttujat. Tässä tutkimuksessa tarkastelimme konstruktiota muotovariaation, leksikaalisen variaation, funktionaalisen variaation ja tekstilajien variaation näkökulmasta, joista kukin valottaa konstruktion käyttöä ja sen hallintaa osin eri tavalla ja joista yhdenkin poisjättäminen yksinkertaistaisi ja osin myös vääristäisi kokonaiskuvaa. Tämä on erityisen relevanttia kompleksisissa konstruktioissa, joiden muotoa ja merkitystä määrittävät samanaikaisesti useat mekanismit. Toinen metodologinen vahvuus on korpusmenetelmien yhdistäminen oikeakielisyysarvioihin. Tieteellisessä keskustelussa on kaivattu korpustutkimuksen ja erilaisten kokeellisten menetelmien runsaampaa yhdistämistä (ks. esim. Gries 2012), ja näin tekemällä onkin saavutettu tuloksia, jotka olisivat jääneet saavuttamattomiin ilman monimenetelmäistä lähestymistä (ks. esim. Gries-Wulff 2005; 2009). Emme tämän tutkimuksen rajoissa paneudu kohdekielenmukaisuuden, kielellisen normin tai virheen käsitteisiin ja niiden määrittelyyn. Näemme kuitenkin, että käyttämämme menetelmä on luonteva ja käyttöpohjaiselle viitekehykselle perusteltu tapa ottaa huomioon nämä seikat ja silti välttää vertailuharha eli ajatus monoliittimaisesta staattisesta ja vaihteluttomasta kohdekielen järjestelmästä, johon oppijankieltä verrataan.

Konstruktion eri muotojen ja merkitysten käyttö on tekstilajikohtaista, sillä jopa tämän tutkimuksen aineistossa olleiden, keskenään verraten samankaltaisten tekstilajien välillä näyttää olevan selviä eroja konstruktion varianttien ja niiden funktioiden distribuutiossa. Käyttöpohjaisesta näkökulmasta on syytä kysyä, missä määrin konstruktion eri merkitysten oppiminen edellyttää niille tyypillisten käyttökontekstien tarvetta ja niille tyypillisten tekstilajien tuntemusta ja rekisterien hallintaa. Niin oppijanenglannin kuin -suomenkin osalta on osoitettu, että edistyneetkin oppijat käyttävät akateemisissa konteksteissa 
tekstilajille epätyypillisiä kielenpiirteitä (Cotton 2010; Paquot ym. 2013; Ivaska 2014b). Kompleksisuuden kannalta voidaan vastaavasti kysyä, minkälainen on morfosyntaktisen kompleksisuuden ja kielen käyttökontekstien hallinnan välinen vaikutussuhde. Tulostemme valossa vaikuttaa siltä, että esimerkiksi E-infinitiivikonstruktion ehtoa ilmaiseva funktio on vasta kehkeytymässä osaksi S2-kirjoittajien spontaanissa tuottamistilanteessa - tässä tapauksessa tenteissä - käyttämää kielirepertoaaria, vaikka sen käyttö S2-kirjoittajilla on muissa tarkastelluissa tekstilajeissa lähellä S1-kirjoittajien käyttöä. Tentit eroavat graduista ja esseistä niin suunnittelun ja huolittelemisen kuin yksityisyyden ja odotettujen lukijoidenkin osalta. S2- ja S1-aineistojen välinen ero saattaa kuvata konstruktion käytön osittaisen oppimisen lisäksi myös tekstilajin ja sille tyypillisen rekisterin osittaista oppimista. Nähdäksemme konstruktiokohtaista oppimista tutkittaessa olisikin syytä ottaa aina huomioon ilmaistujen merkitysten monipuolistumisen (vrt. Seilonen 2013; Kajander 2013) lisäksi myös käyttökontekstien monipuolistuminen ja kullekin käyttökontekstille tyypillisen kielenkäytön tavat. Nämä näkökulmat kuvaavat saman ilmiön eri puolia - on kuitenkin käyttöpohjaisten mallien hengessä muistettava, että kaikki kielenkäyttö ja kielenkäytön tyypillisyys on kontekstikohtaista ja että konstruktioiden oppiminen on siis aina myös tekstilajien oppimista.

\section{Lähteet}

Aijmer, Karin (toim.) 2009: Corpora and Language Teaching. Studies in Corpus Linguistics 33. John Benjamins, Amsterdam.

BARdovi-HARLIG, KATHLEEN - DöRnYei, ZoltáN 1998: Do language learners recognize pragmatic violations? Pragmatic versus grammatical awareness in instructed L2 learning. TESOL Quarterly 32(2), 233-259.

Berkenkotter, Carol - Huckin, Thomas N. 1995: Genre knowledge in disciplinary communication. Lawrence Erlbaum, Hillsdale (NJ).

Biber, Douglas 2006: University Language. A Corpus-Based Study of Spoken and Written Registers. John Benjamins, Amsterdam. DOI: http://dx.doi.org/10.1075/scl.23.

Biber, Douglas - Conrad, Susan M. 2009: Register, Genre, and Style. Cambridge University Press, Cambridge. DOI: http://dx.doi.org/10.1017/CBO9780511814358.

Biber, Douglas - Conrad, Susan M. - Reppen, Randi - Byrd, Pat - Helt, Marie 2002: Speaking and writing in the university: A multidimensional comparison. TESOL Quarterly 36(1), 9-48.

Biber, Douglas. - Conrad, Susan M. - Reppen, Randi - Byrd, Pat - Helt, Marie - Clark, Victoria -Cortes, Viviana - Csomay, Eniko - Urzua, Alfredo 2004: Representing Language Use in the University: Analysis of the TOEFL 2000 Spoken and Written Academic Language Corpus. ETS TOEFL Monograph Series 25. Educational Testing Service, Princeton (NJ).

Bulté, Bram - Housen, Alex 2012: Defining and operationalizing L2 complexity. Alex Housen, Folkert Kuiken ja Ineke Vedder (toim.): Dimensions of L2 performance and proficiency. Complexity, accuracy and fluency in SLA, 21-46. John Benjamins, Amsterdam.

Bybee, JoAn - Eddington, DAvid 2006: A usage-based approach to Spanish verbs of 'becoming'. Language 82(2), 323-355.

Bybee, JoAn - Sandra Thompson 1997: Three frequency effects in syntax. Proceedings of the Twenty-Third Annyal Meeting of the Berkeley Linguistics Society: General Session and Parasession on Pragmatics and Grammatical Structure, 65-85.

Callies, Marcus 2013: Agentivity as a determinant of lexico-syntactic variation in L2 academic writ- 
ing. International Journal of Corpus Linguistics 18(3), 357-390. DOI: 10.1075/ijcl.18.3.05cal.

Callies, Marcus - Zaytseva, Ekaterina 2013: The Corpus of Academic Learner English (CALE) - A new resource for the study and assessment of advanced language proficiency. SYlviane GrangER, GaËtanelle Gilquin ja Fanny Meunier (toim.): Twenty Years of Learner Corpus Research: Looking back, Moving ahead. Corpora and Language in Use - Proceedings 1, 49-59. Presses universitaires de Louvain, Louvain-la-Neuve.

Cadierno, Teresa - Eskildsen, Søren Wind (toim.) 2015: Usage-Based Perspectives on Second Language Learning. Mouton de Gruyter, Berlin.

Chen, Meilin 2013: A corpus study of English phrasal verb use by Chinese, British and American university students. International Journal of Corpus Linguistics 18(3), 418-442.

ConRAd, SUSAN 2005: Corpus linguistics and L2 teaching. Eli Hinkel (toim.): Handbook of research in second language teaching and learning, 393-409. Lawrence Erlbaum, Mahwah, NJ.

2011: Variation in corpora and its pedagogical implications. VAnder Viana, Sonia Zyngier ja Geoff Barnbrook (toim.): Perspectives on corpus linguistics, 47-62. John Benjamins, Amsterdam.

Сотton, Fiona 2010: Critical thinking and evaluative language use in academic writing: A comparative cross-cultural study. George Blue (toim.): Developing Academic Literacy, 73-85. Peter Lang, Oxford.

DĄBRowska, Ewa 2004: Language, Mind and Brain. Some Psychological and Neurological Constraints on Theories of Grammar. Edinburgh University Press, Edinburgh.

2008: Questions with long-distance dependencies: A usage-based perspective. Cognitive Linguistics 19(3), 391-425.

EKLUnd, MerJa 1996: Temporaaliset sivulauseet ja lauseenvastikkeet ulkomaalaisopiskelijoiden kirjoitelmissa. Sivulaudaturtutkielma. Helsingin yliopiston suomen kielen laitos.

EsKOLA, SARI 2002: Syntetisoivat rakenteet kä̈̈nössuomessa. Suomennetun kaunokirjallisuuden ominaispiirteiden tarkastelua korpusmenetelmillä. Joensuun yliopiston humanistisia julkaisuja 30.

Goldberg, Adele E. 1995: Constructions. A Construction Grammar Approach to Argument Structure. The University of Chicago Press, Chicago.

2006: Constructions at Work - The Nature of Generalization in Language. Oxford University Press, Oxford.

Goldberg, Adele E. - Casenheiser, Devin 2008: Construction learning and second language acquisition. Peter Robinson ja Nick C. Ellis (toim.): Cognitive Linguistics and Second Language Acquisition, 197-215. John Benjamins, Amsterdam.

Goldberg, Adele E. - Casenheiser, Devin - Sethuraman, Nitya 2004: Learning argument structure generalizations. Cognitive Linguistics 15(3), 289-316.

Granger, Sylviane 1996: From CA to CIA and back: An integrated approach to computerized bilingual and learner corpora. Karin Aijmer, Bengt Altenberg ja Mats Johansson (toim.): Languages in Contrast, 37-51. Lund University Press, Lund.

2015: Contrastive Interlanguage Analysis: A Reappraisal. International Journal of Learner Corpus Research 1(1), 7-24.

Gries, Stefan Th. 2012: Corpus linguistics, theoretical linguistics, and cognitive/psycholinguistics: towards more and more fruitful exchanges. Joybrato Mukherjee ja Magnus Huber (toim.): Corpus linguistics and variation in English: Theory and description, 41-63. Rodopi, Amsterdam.

Gries, Stefan Th. - Deshors, SANDRA C. 2014: Using regressions to explore deviations between corpus data and a standard/target: two suggestions. Corpora 9(1), 109-136.

Gries, Stefan Th. - Hilpert, Martin 2008: The identification of stages in diachronic data: variabilitybased neighbor clustering. Corpora 3(1), 59-81.

Gries, Stefan Th. - Stefanowitsch, Anatol 2004: Extending collostructional analysis: A corpusbased perspectives on 'alternations'. International Journal of Corpus Linguistics 9(1), 97-129.

Gries, Stefan Th. - WulfF, Stefanie 2005: Do foreign language learners also have constructions? Evidence from priming, sorting and corpora. Francisco José Ruiz de Mendoza Ibáñez (toim.): Annual Review of Cognitive Linguistics 3, 182-200. John Benjamins, Amsterdam. 
Gries, Stefan Th. - Wulff, Stefanie 2009: Psycholinguistic and corpus-linguistic evidence for L2 constructions. Francisco José Ruiz de Mendoza Ibáñez (toim.): Annual Review of Cognitive Linguistics 7, 163-186. John Benjamins, Amsterdam.

Herlin, Ilona 1998: Suomen kun. Suomalaisen Kirjallisuuden Seura, Helsinki.

Herlin, Ilona - Kotilainen, Lari 2004: External factors behind cross-linguistic similarities. Olga Fischer, Muriel Norde ja Harry Perridon (toim.): Up and down the Cline. The Nature of Grammaticalization, 263-279. Amsterdam: John Benjamins.

2005: Itsenäistyvä infinitiivi: 2. infinitiivin inessiivin kehitys kirjakielen aikana. ILONA HerLIN ja LAURA VISAPäÄ (toim.): Elävä kielioppi: suomen infiniittisten rakenteiden dynamiikkaa, 258-291. Suomalaisen Kirjallisuuden Seura, Helsinki.

Hopper, Paul 1987: Emergent grammar. Proceedings of the Thirteenth Annual Meeting of the Berkeley Linguistics Society, 139-157.

Hyland, Ken 2004: Genre and Second Language Writing. The University of Michigan Press, Ann Arbor (MI).

Iкоца, Osmo 2000: Pieni nykysuomen opas. Turun yliopiston suomalaisen ja yleisen kielitieteen laitos, Turku.

Ikola, Osmo - PAlomäki, Ulla - KoItto, AnNA-Kaisa 1989: Suomen murteiden lauseoppia ja tekstikielioppia. SKST 511. Suomalaisen Kirjallisuuden Seura, Helsinki.

Itkonen, Terho - MaAmies, Sari 2007: Uusi kieliopas. Tammi, Helsinki.

IVASKA, ILMARI 2011: Lausetyyppien sekoittuminen edistyneessä oppijansuomessa - näkökulmana eksistentiaalilause. Lähivertailuja. Lähivõrdlusi 21, 65-85. DOI: http://dx.doi.org/10.5128/LV21.03. 2014a: Edistyneen oppijansuomen avainrakenteita. Korpusnäkökulma kahden kielimuodon tyypillisiin rakenteellisiin eroihin. Virittäjä 118(2), 161-193. http://ojs.tsv.fi/index.php/virittaja/ article/view/9368/12373.

2014b: Mahdollisuuden ilmaiseminen S1-suomea ja edistynyttä S2-suomea erottavana piirteenä. Lähivertailuja. Lähivõrdlusi 24, 47-8o. DOI: http://dx.doi.org/10.5128/LV24.02.

2014c: The corpus of advanced learner Finnish (LAS2): Database and toolkit to study academic learner Finnish. Apples - Journal of Applied Language Studies 8(3), 21-38.

2015: Longitudinal changes in academic learner Finnish: A key structure analysis. International Journal of Learner Corpus Research 1(2), 210-241. DOI: http://dx.doi.org/10.1075/ijlcr.1.2.02iva.

KAJANDER, MiкKo 2013: Suomen eksistentiaalilause toisen kielen oppimisen polulla. Jyväskylä Studies in Humanities 220. Jyväskylän yliopisto, Jyväskylä.

KURKI, TOMmI 2016: [Sähköpostiviesti]. Lähetetty 13.3.2016. Kirjoittajien hallussa.

Larsen-Freeman, Diane 1997: Chaos/complexity and second language acquisition. Applied Linguistics 18(2), 141-165.

Larsen-Freeman, Diane - Cameron, Lynne 2008: Complex Systems and Applied Linguistics. Oxford University Press, Oxford.

LAURANTO, YRJÖ 1997: Ensi askeleita paikallissijojen käyttöön. Espanjankielisten suomenoppijoiden sisäja ulkopaikallissijat konseptuaalisen semantiikan näkökulmasta. Kakkoskieli 2. Helsingin yliopiston suomen kielen laitos.

LINDÉN, EEVA 1961: Temporaalirakenne suomen murteissa. Virittäjä 65(2), 194-210.

— 1971: Temporaalirakenne kirjoitetussa kielessä. Virittäjä 75(1), 23-34.

Martin, Maisa 2013. Sentences and clauses as complexity measures in second language writing: a segmentation experiment. Maria Järventausta ja Marko Pantermöller (toim.): Finnische Sprache, Literatur und Kultur im deutschsprachigen Raum - Suomen kieli, kirjallisuus ja kulttuuri saksankielisellä alueella, 185-198. VSUA 85. Harrassowitz, Wiesbaden.

Martin, Maisa - Mustonen, Sanna- Reiman, Nina- Seilonen, Marja 2010: On becoming an independent user. Inge Bartning, Maisa Martin ja Ineke Wedder (toim.): Communicative Proficiency and Linguistic Development: Intersections between SLA and Language Testing Research, 57-80. Eurosla: Monograph Series (1).

MeUnier, FANNy 2012: Formulaic language and language teaching. Annual Review of Applied Linguistics 32(1), 111-129. 
Mustonen, Sanna 2015: Käytössä kehittyvä kieli: Paikat ja tilat suomi toisena kielenä -oppijoiden teksteissä. Jyväskylä Studies in Humanities 255. Jyväskylän yliopisto, Jyväskylä.

Noordman, LeO - De BlizZer, Femke 2000: On the processing of clausal relations. Elizabeth CouperKuhlen ja Bernd Kortmann (toim.): Cause - Condition - Concession - Contrast: Cognitive and Discourse Perspectives, 35-56. Mouton de Gruyter, Berlin.

O’Keeffe, Anne - McCarthy, Michael - Carter, Ronald 2007: From Corpus to Classroom: Language Use and Language Teaching. Cambridge University Press, Cambridge.

Olshtain, Elite - Blum-Kulka, Shoshana 1985: Degree of approximation: Nonnative reactions to native speech act behavior. Susan M. Gass ja Carolyn G. Madden (toim.): Input in second language acquisition, 303-325. Newbury House, Rowley (MA).

Paquot, Magali - Hasselgård, Hilde - Oksefjell Ebeling, Signe 2013: Writer/reader visibility in learner writing across genres: A comparison of the French and Norwegian components of the ICLE and VESPA learner corpora. Sylviane Granger, Gä̈tanelle Gilquin ja Fanny MeuNIER (toim.): Twenty Years of Learner Corpus Research. Looking Back, Moving Ahead. Proceedings of the First Learner Corpus Research Conference (LCR 2011), 377-387. Presses Universitaires de Louvain, Louvain-la-Neuve.

R Core Team 2015: R: A language and environment for statistical computing. R Foundation for Statistical Computing, Vienna:. http://www.R-project.org/.

Schutz, Natassia 2013: How specific is English for Academic Purposes? A look at verbs in business, linguistics and medical research articles. Gisle ANDERSEn ja Kristin Bech (toim.): English Corpus Linguistics: Variation in Time, Space and Genre, 237-257. Rodopi, Amsterdam.

SeIlonen, MARJA 2013: Epäsuora henkilöön viittaaminen oppijansuomessa. Jyväskylä Studies in Humanities 197. Jyväskylän yliopisto, Jyväskylä.

SiITONEN, KiRSTI 2014: Learners' dilemma: an example of complexity in academic Finnish. The frequency and use of the E infinitive passive in L2 and L1 Finnish. Pekka Lintunen, Maija S. Peltola ja Mari-Lissa Varila (toim.): AFinLA-e Soveltavan kielitieteen tutkimuksia 6, 134-148.

Sirtonen, Kirsti - Mizuno, Manami 2010: Suomen monitahoinen possessiivisuffiksi ja suomenoppija. Lähivertailuja. Lähivõrdlusi 19, 136-159. DOI: http://dx.doi.org/10.5128/LV19.09.

Sirtonen, Kirsti - Niemelä, Jenny 2011: Mitä pitkittäistutkimus paljastaa edistyneiden suomenoppijoiden kielitaidosta? Lähivertailuja. Lähivõrdlusi 21, 242-279. DOI: http://dx.doi.org/10.5128/ LV21.10.

Sirvelt, Keaty - Mustonen, SAnna 2013: Lähdekielen vaikutus ja kielitaitotasot: paikallissijojen kehitys oppijansuomessa. Lähivertailuja. Lähivõrdlusi 23, 341-370.

Sinclair, John 1991: Corpus, Concordance, Collocation. Oxford University Press, Oxford.

Swales, John 1990: Genre Analysis: English in Academic and Research Setting. Cambridge University Press, Cambridge.

Tolvanen, Mira 2004: Lauseenvastikkeet ei-syntyperäisten kielenpuhujien ylioppilasaineissa. Pro gradu -tutkielma. Helsingin yliopiston suomen kielen laitos.

Tomasello, Michael 2003: Constructing a Language. A Usage-Based Theory of Language Acquisition. Harvard University Press, Cambridge.

VISK = Auli Hakulinen - Maria Vilkuna - Rittta Korhonen - Vesa Koivisto - Tarja Rittta Heinonen - Irja AlHo 2004: Iso suomen kielioppi. Suomalaisen Kirjallisuuden Seura, Helsinki. Verkkoversio, http://scripta.kotus.fi/visk URN:ISBN:978-952-5446-35-7. 


\title{
ILMARI IVASKA - KIRSTI SIITONEN: The tehdessä construction in advanced learner Finnish
}

Many Finnish infinitive constructions can be considered to be complex in terms of their morphological structure and their syntactic-semantic nature, and this has been thought to also affect the learning process of Finnish as a second language $\left(\mathrm{F}_{2}\right)$ learners. This article focuses on the E infinitive construction (e.g. tehdess $\ddot{a}$ and tehtäessä) and its use in the different genres of academic texts of $\mathrm{F}_{2}$ learners in comparison to those of native ( $\left.\mathrm{F}_{1}\right)$ learners of Finnish. The approach is corpus-based, with data from the Corpus of Advanced Learner Finnish. Following the usage-based models of language, we supplement the corpus analysis with a grammaticality judgement survey taken by $\mathrm{F}_{1}$ and $\mathrm{F}_{2}$ learners. The research questions are as follows: 1 ) What is the use of $\mathrm{E}$ infinitive constructions like quantitatively and qualitatively in different genres of $\mathrm{F}_{2}$ and $\mathrm{F}_{1}$ academic writing? 2) Do $\mathrm{F}_{1}$ learners of Finnish pay attention to potential ungrammaticality of $\mathrm{F}_{2}$ texts and are their observations uniform?

The article shows that the construction is, in general, relatively rare and that the active construction is more frequent in both $\mathrm{F}_{2}$ and $\mathrm{F}_{1}$ data. As far as genres go, the construction is more rarely used in exam essays and research papers of $\mathrm{F}_{2}$ learners than $\mathrm{F}_{1}$ learners. Most commonly, the construction expresses a temporal relationship, although it is used also to express a conditional as well as a causal relationship. The temporal relationship is typical for the active constructions whereas the conditional relationship dominates the use of passive constructions. The most remarkable difference between the two genres is that the conditional relationship is especially typical for the exam essays. The most notable difference between the $\mathrm{F}_{2}$ and $\mathrm{F}_{1}$ data is that the most typical functions cover a greater part of all the occurrences in the $\mathrm{F}_{2}$ data than they do in the $\mathrm{F}_{1}$ data. The grammaticality judgements show that $\mathrm{F}_{1}$ learners recognize ungrammatical constructions relatively similarly, but that there are different degrees of ungrammaticality. In all of the constructions considered clearly ungrammatical, the function is not prototypical for the construction or it is unclear.

The results suggest that acquisition expands from more typical expressions to greater variation. Furthermore, the level of acquisition and the genre at hand inherently are intertwined. Less typical use may also be more prone to ungrammaticality. The method used shows that combining different methodologies gives a more detailed and fine-grained view on learning, and that leaving any of the now implemented points of view out of the analysis would falsely simplify a multi-faceted phenomenon.

\author{
Ilmari Ivaska \\ ilmari.ivaska@unibo.it \\ Dipartimento di Interpretazione e Traduzione - Università di Bologna \\ Corso della Repubblica 136 \\ 47121 Forlì, Italia \\ Kirsti Siitonen \\ kirsti.siitonen@utu.fi \\ Suomen kieli ja suomalais-ugrilainen kielentutkimus \\ 20014 Turun yliopisto
}

